\title{
PERSEPSI KENYAMANAN PARA PENGHUNI ASRAMA POLISI DI LEMBAGA PENDIDIKAN DAN PELATIHAN KEPOLISIAN REPUBLIK INDONESIA, AKADEMI KEPOLISIAN
}

\author{
Varian Dedy Hartawan ${ }^{1 *}$, Erni Setyowati ${ }^{2}$, Atik Suprapti ${ }^{2}$ \\ *) Corresponding author email : variandedy15@gmail.com \\ 1) Lembaga Ketahanan Nasional Republik Indonesia, Jakarta - Indonesia \\ 2) Departemen Arsitektur, Fakultas Teknik, Universitas Diponegoro, Semarang - Indonesia
}

\author{
Article info \\ MODUL vol 19 no 1, issues period 2019 \\ Doi $\quad: 10.14710 / \mathrm{mdl} .19 .1 .2019 .33-46$ \\ Received : 2nd may 2019 \\ Revised : 22th may 2019 \\ Accepted : 22nd may 2019
}

\section{Abstract}

As a primary need, shelter or boards are often to the top priority in human life which must be fulfilled after clothing and food. The Police Dormitory from Indonesian Republic Police Education And Training Institutions - Police Academy or abbreviated in Indonesian "Lemdiklat Polri - Akpol" is residential facility in the police dormitory provided for personnel and staff who teach or served in the Police Academy both members of the National Police or PNS (Goverment Employees). Not infrequently this dormitory are also inhabited more than two years by its members who serve in the Indonesian Republic Police Education And Training Instituitions - Police Academy. The majority of residents can be said to be decent enough to buy, or rent and inhabit outside the plice dormitory which has far better conditions than the police dormitory itself. This paper aims to determine the factors that make them stay at home to live there, even thought they can rent or buy more suitable home to live. The method used is mixing of qualitative methods and quantitative methods called mixed methods, and also look at the psychological and economic aspects of them. The results of the study reveal that there are a numbers of reasons for neighboring life that are safe, comfortable, economically affordable, the tranquility and natural silence in the surrounding area along with pollution - free air makes the residents still remain even though this location is far from the economic center in mainly.

Keywords: Dormitory; Residential; Police Academy

Varian Dedy Hartawan, Erni Setyowati, Atik Suprapti

\section{PENDAHULUAN}

Hunian atau tempat tinggal merupakan salah satu kebutuhan primer bagi manusia selain sandang, dan pangan. Sebagai kebutuhan primer, maka hunian merupakan salah satu benda kebutuhan manusia yang digunakan dalam jangka waktu yang sangat lama. Dari segi kepemilikan, hunian ada yang dimiliki secara pribadi, disewakan atau dipinjamkan. Asrama polisi merupakan salah satu hunian fasilitas yang dipinjamkan sebagai bentuk fasilitas dari institusi yang berdinas kepada rekannya maupun pekerjanya. Lemdiklat Polri Akpol yang berlokasi di Kota Semarang, Provinsi Jawa Tengah merupakan sebuah kawasan institusi di bawah naungan Lemdiklat Polri yang berlokasi di Kebayoran Lama, Jakarta Selatan, DKI Jakarta. Akademi Kepolisian yang merupakan sebuah kawasan pendidikan yang tentunya memiliki berbagai macam fasilitas fasilitas penunjang, salah satunya adalah asrama. Banyak unit asrama yang sudah dihuni lebih dari dua tahun. Jika dilihat dari penghasilan dari para penghuninya, mereka sebenarnya dapat membeli atau menyewa hunian di luar asrama polisi yang dilihat dari segi kenyamanan dan estetika lebih baik apabila dibandingkan dengan asrama polisi di Lemdiklat Polri Akpol ini. Penulisan ini bertujuan untuk mengetahui faktor apa saja yang mempengaruhi para penghuni memilih untuk menetap di asrama dibandingkan membeli atau menyewa rumah di luar asrama Lemdiklat Polri - Akpol.

\section{TINJAUAN PUSTAKA}

Permukiman memiliki dua unsur utama yang terdiri dari isi/ content, dan wadah / container yang kemudian dijabarkan kembali menjadi human, society, shell, nature dan network (Doxiadis, 1970). Sedangkan menurut Kuswartojo permukiman merupakan bagian dari suatu lingkungan hidup yang berada di luar kawasan lindung yang berupa perkotaan dan juga 
perkampungan yang merupakan hunian tempat tinggal yang mendukung sosialisasi dalam perikehidupan dan penghidupan (Kuswartojo, Tjuk \& Salim, Suparti Amir, 1997). Bagian permukiman yang menjadi wadah merupakan paduan dari tiga unsur yaitu : Alam (tanah, air, udara), lindungan (shells), dan jaringan (networks), dimana isinya adalah manusia dan masyarakat. Alam adalah unsur dasar dan diciptakan suatu lokasi untuk berlindung (rumah dan gedung lainnya) sebagai tempat tinggal manusia. Sedangkan jaringan lainnya seperti jalan, jaringan utilitas, adalah unsur yang memfasilitasi hubungan antar sesama (Kuswartojo dan Salim, 1997). Dari ini dapat dikatakan bahwa permukiman adalah paduan antara unsur : Manusia dengan masyarakatnya, alam dan unsur buatan sebagaimana digambarkan melalui ekistiknya (Doxiadis, 1970). Kepribadian seseorang tidak ada gunanya apabila seseorang menyendiri atau tidak ada hubungan sosial karena sejak lahir hingga kematian tetap membutuhkan interaksi sosial dengan masyarakat sekitar. Sulivan tetap mengakui adanya unsur - unsur keturunan (hereditas) pada manusia, tetapi adanya kekhasan tingkah laku individu tetaplah sebagai hasil interaksi - interaksi sosial (Fudyartanta, 2012). Negara Indonesia adalah negara yang beriklim tropis dan mendapatkan cahaya matahari yang besar disebabkan arah pencahayaan matahari cenderung tegak dan menyengat (Lippsmeier, 1994) . Dari penelitian penelitian suhu yang cocok dan nyaman untuk kulit manusia adalah $20^{\circ} \mathrm{C}$ (Setyowati, 2015). Suatu objek memiliki temperatur atau suhu udara Sedangkan semakin tinggi temperatur maka semakin tinggi pula kemampuan udara menyerap air, apabila temperatur rendah akan mengakibatkan kelembapan udara semakin tinggi akibatnya kemampuan udara dalam menyerap air semakin melemah (Setyowati, 2015). Dalam merencanakan suatu bangunan wajib memiliki faktor - faktor iklim untuk mencapai kenyamanan thermal yang harus diperhatikan, antara lain adalah :

1. Temperatur atau Suhu Udara

Semakin ke arah kutub, temperatur dan radiasi otomatis akan semakin berkurang. Penyebab pengurangan tersebut diantaranya adalah letak geografis, kondisi atmosfir, jenis permukaan bumi baik dataran maupun peairan suhu badan manusia, hewan pemilihan bahan bangunan serta penetapan kondisi iklim subtropis atau tropis (Setyowati 2015). Suhu udara merupakan faktor yang sangat berpengaruh terhadap kondisi nyaman (termal) manusia menurut Hoppe (1988) Suhu manusia akan naik apabila suhu ruang dinaikkan sekitar $21^{\circ} \mathrm{C}$ apabila kenaikan suhu ruang tidak akan mnenyebabkan suhu kulit manusia tersebut menjadi naik, namun akan menyebabkan keluarnya keringat dari pori - pori kulit manusia untuk beradaptasi. Untuk suhu ruangan $20^{\circ} \mathrm{C}$ merupakan suhu nyaman untuk kulit (Hoppe, 1988)

\section{Humadity atau Kelembaban Udara}

Semakin tinggi temperatur maka semakin tinggi kemampuan udara menyerap air, apabila temperatur rendah akan mengakibatkan kelembaban udara semakin tinggi akibat kemampuan udara menyerap air melemah. Pengaruh kelembaban udara pada kenyamanan ruang tidak sebesar pengaruh pada perubahan suhu udara (Hoppe, 1988).

\section{Gerakan Udara}

Gerakan udara terjadi disebabkan oleh pemanasan lapisan - lapisan udara yang berbeda - beda. Skalanya berkisar antara kekuatan angin 0 sampai 12 (skala Beaufort). Semakin kasar permukaan angin yang dilalui maka semakin tebal lapisan udara yang tertinggal diam di dasar. Bentuk topografi yang berbukit - bukit, vegetasi, dan bangunan dapat menghambat atau membelokkan gerakan udara (Setyowati 2015). Faktor kecepatan udara juga mempengaruhi kecepatan termal yang memiliki kesimpulan (Hoppe , 1988). Dengan semakin besar kecepatan udara maka semakin rendah suhu kulit manusia. Ada beberapa faktor yang mempengaruhi kecepatan perubahan angin diantaranya adalah :

- Besarnya kecepatan angin yang berada pada tapak perancangan.

- Arah datang angin yang menerpa fasad - fasad bangunan

- Bentuk fasad yang sesuai untuk meminimalisir kecepatan angin yang menerpa bangunan

Dalam mengatasi faktor tersebut dapat menggunakan metoda double layer atau fasad kedua yang dapat mereduksi panas secara langsung. Metoda ini dapat benbentuk seperti jalusi atau louvre dan sebagainya. Fasad double layer memiliki keungulan dalam memasukan angin ke dalam ruangan tereduksi 50\% panasnya sehingga kenyamanan lebih terjaga (Napitupulu 2014).

Pergerakan udara disebabkan oleh pemanasan lapisan udara yang berbeda. Skala berkisar 0 sampai 12 (skala beaufort). Semakin kasar permukaan angin yang dilalui maka semakin tebal lapisan udara yang tertinggal diam di dasar model topografi yang berbukit, bangunan tinggi, vegetasi dapat menghambat maupun membelokkan gerakan udara (Setyowati, 2015). Dari pengukuran suhu pada temperatur $26^{\circ} \mathrm{C}$ TE umumnya manusia sudah mulai berkeringat. Daya tahan dan kemampuan kerja manusia mulai menurun pada temperatur $26^{\circ} \mathrm{C} \mathrm{TE}-30^{\circ} \mathrm{C}$ TE, kondisi lingkungan yang sukar mulai dirasakan pada suhu $33,5^{\circ} \mathrm{C}$ TE $35,5^{\circ} \mathrm{C}$ TE, dan pada suhu $35^{\circ} \mathrm{C}-36^{\circ} \mathrm{C}$ TE kondisi lingkungan tidak dapat ditolerir lagi. Produktifitas manusia cenderung turun dan berkurang atau rendah pada kondisi udara yang tidak nyaman seperti terlalu panas atau terlalu dingin (Idealistina, 1991). Pada daerah tropis khususnya di Indonesia, tampak timur dan tampak 
barat bangunan merupakan daerah yang banyak terkena radiasi matahari dan mayoritas dari masyarakatnya menggunakan bukaan yang cukup lebar. Bukaan tersebut difungsikan selain untuk fungsi artistik atau estetika, juga difungsikan sebagai teknik dalam menyederhanakan struktur dari bangunan untuk sarana proses pendinginan evaporasi dan penghapusan panas pada dalam ruangan yang diakibatkan oleh besarnya radiasi itu sendiri (Susilowati dan Wahyudi 2014).

Kenyamanan Thermal adalah kenyamanan atau merupakan unsur yang sangat penting bagi kegiatan aktifitas para manusia karena menyangkut akan kenyamanan kondisi suhu ruangan di dalamnya. Manusia merasakan hawa panas dan hawa dingin melalui sensor perasa yang ada di kulit setiap manusia terhadap stimuli suhu yang ada di lingkungan sekitar, sendor ini akan memberikan perintah ke otak bagian tubuh mana yang akan melakukan antisipasi untuk mempertahankan diri sekitar suhu $37^{\circ} \mathrm{C}$ (Rilatupa ,2008).

Iklim tropis adalah iklim yang memiliki ciri yang sangat dominan dengan tingginya suhu rata - rata harian bila dibandingkan pada iklim lain. Dengan adanya hal ini maka menimbulkan berbagai macam persoalan yang berkaitan dengan wilayah dan tempat manusia bermukim serta melangsungkan aktifitasnya sehari hari (Karyono, 2001). Beberapa macam persoalan tersebut diantaranya adalah :

A. Radiasi Matahari Yang Menimbulkan Pemanasan.

Panas yang ditimbulkan oleh radiasi matahari permukaan bumi tentunya akan memiliki perbedaan saat penyerapan maupun pemantulannya, untuk masyarakat Indonesia dalam menggunakan warna permukaan (dinding, atap) menentukan jumlah panas yang diserap. Warna terang pada suatu benda akan cenderung lebih banyak memantulkan panas dari matahari sedangkan warna yang bersifat gelap akan jauh lebih banyak menyerap panas dari radiasi matahari.

B. Terjadinya Urban Heat Island (UHI).

Urban Heat Island adalah efek yang timbul pada wilayah kota yang bersifat metropolitan dan secara signifikan memiliki sifat panas pada jam aktifitas atau jam kerja antara pagi hingga sore hari. Suhu sangat berbeda drastis pada siang hari saat matahari berada di atas kepala dan malam hari saat matahari terbenam. Negara Indonesia sebagai negara yang masih berkembang pada kota - kotanya menggunakan penutup permukaan tanah (perkerasan) beton, aspal yang digunakan sebagai jalan dan parkir radiasi mataharinya akan jatuh di permukaan namun dilepaskan lagi ke udara. Sebagian besar area perkotaan di Indonesia tertutup oleh material yang memiliki sifat keras yang semuanya menyerap panas sehingga mengakibatkan terjadinya efek Heat Urband Island atau suhu udara menjadi lebih tinggi.

Penelitian ini erat kaitannya dengan persepsi karena berkaitan dengan faktor kenyamanan dalam menghuni. Persepsi Menurut Paul adalah proses hasil penginderaan setelah manusia menginderakan objek di lingkungannya dan timbulah makna tentang objek itu pada diri manusia itu sendiri. Skema persepsi yang dibuat oleh Paul adalah sebagai berikut (Paul, 1978) :

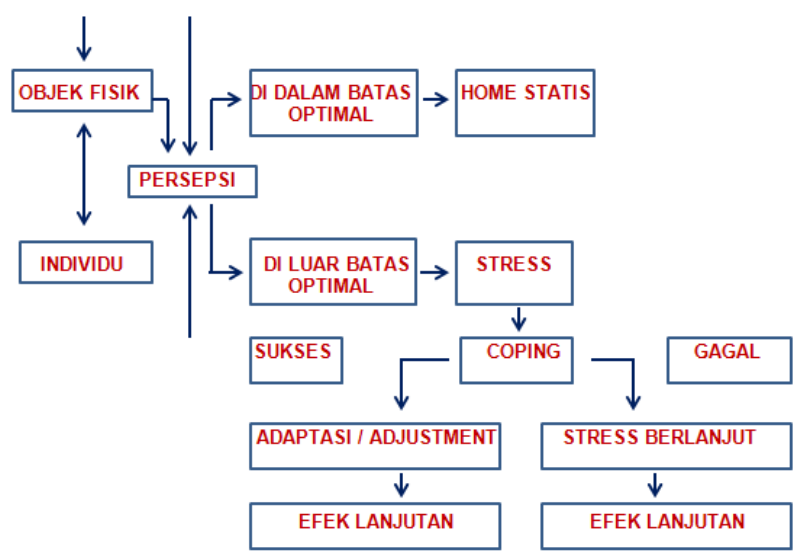

Gambar 1. Alur persepsi manusia (Paul, 1978)

Dalam urutan skema di atas bahwa tahapan awal hubungan manusia dan sekitarnya adalah kontak fisik dari sesama manusia itu sendiri dengan objek di lingkungan sekitarnya. Setiap objek tampil dengan kemanfaatannya masing - masing, sedangkan individu datang dengan sifat - sifat individualnya masing masing, pengalaman masa lalunya, dan kepribadiannya sendiri (Ekman, P., \& Friesen, W.V. 1978).

Hasil interaksi menghasilkan persepsi individu tentang objek. Apabila persepsi itu muncul dan masih berada dalam di bawah ambang batas optimal maka disebut individu itu dalam kondisi homeostatis atau seimbang. Namun apabila melebihi batas optimal maka individu akan mengalami stress dalam dirinya sendiri. Hasil dari meniru kebiasaan atau hasil dari copying behaviour memiliki dua kemungkinan yang dihasilkan. Kemungkinan pertama adalah tidak ada hasil sama sekali atau tidak sesuai dengan harapan yang diharapkan dan hal ini dapat menjadi penyebab gejala stress semakin berlanjut dan bertambah parah. Kemungkinan kedua apabila berhasil maka terjadi penyesuaian antara diri manusia itu dengan lingkungan adaptasinya atau penyesuaian keadaan lingkungan pada diri individu atau adjustment. Penyelesaian yang dicapai menghasilkan istilah "Temperatur Efektif" atau "TE". (Houghton dan Yahlou,1923). Temperatur Efektif ini ditentukan dengan percobaan yang mencakup temperatur, kelembaban, dan gerakan udara. Sesuai dengan penelitian menunjukkan 
beberapa objek penelitian yang dikumpulkan berkaitan dengan batas kenyamaan (dalam Temperatur Efektif / TE) berbeda tergantung pada lokasi geografis subjek di mana manusia itu menetap. Tabel yang di berikan warna biru dan kotak biru adalah tabel kota Jakarta, Negara Indonesia dengan kelompok manusia nya adalah warga negara Indonesia dengan batas kenyamanan sekitar $20^{\circ}$ $\mathrm{C}-26^{\circ} \mathrm{C}$ Temperatur Efektif (TE). (Lihat tabel 1).

Tabel 1. Batas Kenyamanan Bangunan Dalam Temperatur Efektif Derajat Celcius $\left({ }^{0} \mathrm{C}\right)$ Pada Setiap Negara

\begin{tabular}{|c|c|c|c|}
\hline Pengarang & Tempat & $\begin{array}{l}\text { Kelompok } \\
\text { Manusia } \\
\end{array}$ & $\begin{array}{l}\text { Batas } \\
\text { Kenyamanan }\end{array}$ \\
\hline ASHRAE & $\begin{array}{l}\text { USA Selatan } \\
\left(30^{\circ} \mathrm{LU}\right)\end{array}$ & Peneliti & $\begin{array}{c}20,5^{\circ} \mathrm{C}-24,5^{\circ} \\
\text { C TE }\end{array}$ \\
\hline Rao & $\begin{array}{c}\text { Calcutta }\left(22^{\circ}\right. \\
\text { LU) }\end{array}$ & India & $\begin{array}{c}20^{\circ} \mathrm{C}-24,5^{\circ} \mathrm{C} \\
\mathrm{TE}\end{array}$ \\
\hline Webb & $\begin{array}{c}\text { Singapura } \\
\text { Khatulistiwa }\end{array}$ & $\begin{array}{c}\text { Malaysia } \\
\text { Cina }\end{array}$ & $\begin{array}{c}25^{\circ} \mathrm{C}-27^{\circ} \mathrm{C} \\
\mathrm{TE}\end{array}$ \\
\hline Mom & $\begin{array}{c}{\text { Jakarta }\left(6^{\circ}\right.}^{\circ} \\
\text { LS) }\end{array}$ & Indonesia & $\begin{array}{c}20^{\circ} \mathrm{C}-26^{\circ} \mathrm{C} \\
\mathrm{TE}\end{array}$ \\
\hline Ellis & $\begin{array}{c}\text { Singapura } \\
\text { Khatulistiwa }\end{array}$ & Eropa & $\begin{array}{c}22^{\circ} \mathrm{C}-26^{\circ} \mathrm{C} \\
\mathrm{TE}\end{array}$ \\
\hline
\end{tabular}

\section{METODOLOGI PENELITIAN}

Metode yang digunakan untuk penelitian ini adalah merupakan gabungan antara metode kuantitatif dan metode kualitatif dan disebut metode campuran atau Mix Method. Penelitian kualitatif atau post positivistik memungkinkan peneliti untuk langsung memasuki obyek atau lapangan walaupun belum memiliki permasalahan yang jelas (Sugiyono, 2013) . Penelitian kualitatif juga dimaksudkan untuk mennghasilkan ilmu - ilmu lunak, dan pada intinya merupakan sebuah metode yang bersifat ke arah pemahaman dan mengarah kesuatu hal yang merupakan keunikan yang ada di lingkungan tersebut melalui pemahaman dan penemuan yang terdapat di lokasi objek. Sedangkan penelitian kuantitatif atau positivistik menurut Hussein mengarahkan peneliti untuk menuyusun dan memperoleh ilmu hard science (pengetahuan keras) yang bebasis pada objektivitas dan kontrol yang beroperasi dengan aturan - aturan ketat, seperti logika, kebenaran, hukum, aksioma, dan prediksi data (Hussein, 2019). Kenyamanan termal menurut Lippsmeier dipengaruhi oleh enam faktor yaitu, Air Temperature, Air Humadity, Temperature From Radiation of Roof and Walls, Air Velocity, Lighting, Distribution of Radiation on Walls. Dari enam faktor yang dipakai adalah tiga faktor yaitu Air Temperature, Air Humadity, dan Air Velocity. Untuk Konsep Operasional menggunakan Metode kuantitatif membahas kenyamanan termal yang berada di hunian rumah dinas asrama polisi di Akpol tersebut (Syahmir, 1980). Tabel di bawah ini adalah data tabel penjelasan dari kenyamanan termal yang dipakai (Lihat tabel 2).

Tabel 2. Parameter dan Indikator dalam Indikator penelitian

\begin{tabular}{|c|c|c|c|}
\hline No & $\begin{array}{l}\text { Posisi } \\
\text { Bukaan / } \\
\text { Variabel }\end{array}$ & Indikator & Parameter \\
\hline 1. & $\begin{array}{c}\text { Suhu/ } \\
\text { Thermal }\end{array}$ & $\begin{array}{l}\text { Derajat Suhu } \\
\text { dalam Celcius }\end{array}$ & $\begin{array}{c}22.5^{\circ} \mathrm{C}-29,5^{\circ} \mathrm{C} \text { (Dalam } \\
\text { Lippmeier 1997) } \\
\text { Alat Ukur : Termometer }\end{array}$ \\
\hline 2 & Kelembaban & $\begin{array}{c}\text { Persentase } \\
\text { Kelembaban }\end{array}$ & $\begin{array}{c}20 \%-50 \% \text { (Dalam } \\
\text { Lippsmeier 1997) } \\
\text { Alat Ukur: Anemometer }\end{array}$ \\
\hline 3 & $\begin{array}{l}\text { Angin } \\
\text { (bebas) }\end{array}$ & $\begin{array}{l}\text { Radius } \\
\text { Kecepatan } \\
\text { Angin }\end{array}$ & $\begin{array}{c}0,15 \mathrm{~m} / \mathrm{s}-0,25 \mathrm{~m} / \mathrm{s} \\
\text { (Dalam Pandiangan, } \\
\text { dkk) } \\
\text { Alat Ukur : Barometer }\end{array}$ \\
\hline
\end{tabular}

Data berdasarkan hasil - hasil digunakan untuk pemilihan sampel unit hunian di asrama Lemdiklat Polri - Akpol, sedangkan metode kualitatif untuk meneliti faktor - faktor apa saja yang mempengaruhi penghuni memilih untuk menetap di asrama dibandingkan membeli atau menyewa hunian di luar area. Untuk metode kualitatif data yang didapat adalah dari penjelasan para penghuni sedangkan untuk metode kuantitatif data yang didapat dan yang digunakan mengacu pada kecepatan angin dalam $(\mathrm{m} / \mathrm{s})$, kelembaban udara $(\mathrm{Rh})$, beserta temperatur udara $\left({ }^{\circ} \mathrm{C}\right)$ (Lihat tabel 2). Untuk kediaman yang dijadikan objek adalah 10 rumah dinas, sedangkan ruang yang dijadikan objek untuk pengukuran adalah 3 ruang yaitu ( teras, ruang keluarga, beserta ruang tidur). Berdasarkan waktu dari pukul 05:00 WIB hingga pukul 22:00 WIB, dan diukur setiap satu jam sekali.

Untuk sampling yang digunakan terdapat dua macam sampling, yaitu Random Sampling dan Non Probablity Sampling. Penelitian ini dilakukan dengan metode kuantitatif menggunakan metode Random Sampling dengan tipe cluster sampling yang menggunakan pemilihan secara purposive. Mengguakan cluster sampling dikarenakan populasi yang berupa grup atau cluster sehinggga beberapa grup tersebut dijadikan sebagai sampel. Untuk cluster tahap 1 asrama polisi dibagi menjadi beberapa blok hunian, peneliti mengkategorikannya sebagai hunian yang dihuni oleh pamen dan pama (berdasarkan pangkat/gaji perbulan). Cluster tahap kedua dari rumah pamen dan pama tersebut diambil hanya pegawai yang menghuni lebih dari 2 tahun. Suatu penemuan masalah atau problem finding penelitian juga dibagi menjadi $3 P$ yaitu melalui 
Paper, dengan mempelajari dokumen, buku, majalah, laporan penelitian atau penemuan sebelumnya. Selanjutnya Personal, dengan melakukan diskusi diskusi ke berbagai para ahli maupun warga yang sedang berada atau yang menetap di lokasi penelitian. Dan terakhir Place, dengan mengamati daerah lokasi penelitian yang dijadikan objek yang akan dijadikan penelitian (Arikunto, 2002). Sumber masalah juga dapat diperoleh dari kegiatan - kegiatan sebagai berikut, diantaranya adalah berupa bacaan jurnal, laporan laporan hasil penelitian, skripsi, tesis, disertasi, buku, teks, dan internet, selain itu yang tidak melalui media adalah dari seminar, lokakarya, diskusi, penemuan ilmiah, pengamatan, pengalaman, serta intuisi kemampuan untuk memahami sesuatu tanpa melalui penalaran rasional dan inteletualitas (Sarmanu ,2004).

\section{HASIL PENELITIAN DAN PEMBAHASAN}

Lokasi penelitian ini berada di asrama polisi Lemdiklat Polri - Akpol dan berada di Kota Semarang, tepatnya berada di kecamatan Gajah Mungkur. Karena jumlah unitnya cukup banyak maka dipilihlah lokasi - lokasi penelitian yang menggunakan sampling. Rumah dinas Blok B, Blok $\mathrm{C}$, Blok $\mathrm{E}$ dan Blok $\mathrm{H}$ dipilih dijadikan objek karena para perwira yang menempati rumah dinas pada blok tersebut sudah berdinas sekitar 2 tahun di Lemdiklat Polri Akpol, namun hingga sekarang mereka masih bersedia atau dapat dikatakan betah untuk menetap di kediaman rumah dinasnya, tanpa harus keluar untuk menyewa dan menghuni kediaman lainnya yang jauh lebih layak dihuni dibandingkan rumah dinas masing - masing. Serta pendapatan mereka dapat dikatakan sudah cukup memadai untuk menghuni kediaman di luar asrama polisi Akademi Kepolisian. Berikut adalah data - data kualitatif dan kuantitatif beserta hasil wawancara dari para penghuni unit asrama yang dipilih beserta mengenai alasan - alasan apa saja mereka tetap betah bermukim di rumah dinas Lemdiklat Polri - Akpol.

\section{Rumah Dinas Blok B}

Pada area blok B ada dua unit rumah dinas yang dijadikan sampel, yaitu rumah dinas Blok B 4 dan Blok B 27. Berikut adalah data data yang didapat dari rumah dinas Blok B 4 dan Blok B 27 melalui metode kualitatif dan metode kuantitatif. (Lihat Gambar 2)

\section{A. Rumah Dinas Blok B 4}

Rumah Dinas Blok B 4 adalah rumah dinas yang terletak di Jalan K.S. Tubun dan merupakan akses jalan yang bersifat satu arah dekat dengan pintu gerbang samping dari area Akademi Kepolisian (Lihat Gambar 2). Jalan ini menjadi jalan utama bagi para personel Polri yang sedang menjabat di jajaran Akademi Kepolisian, luar Akademi Kepolisian, PNS dan warga umum yang akan berkunjung ke dalam area Akademi Kepolisian. (Lihat Gambar 2)

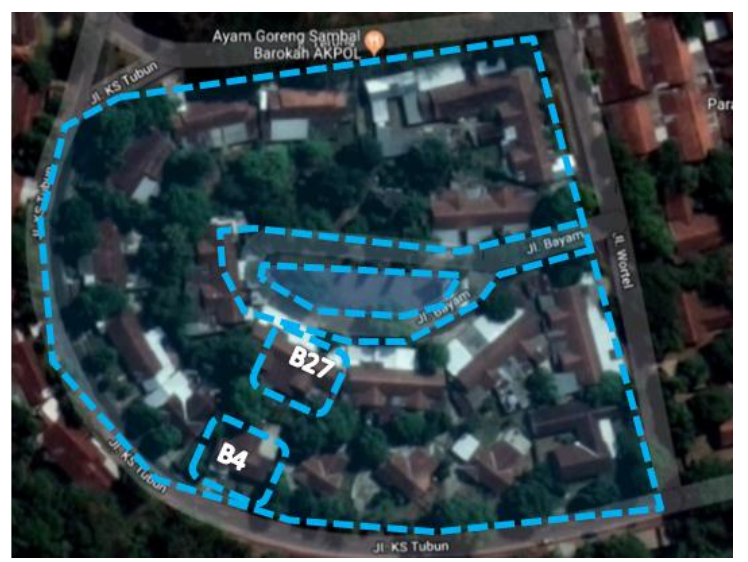

Gambar 2. Tampak atas rumah dinas Blok B 4 dan B 27.

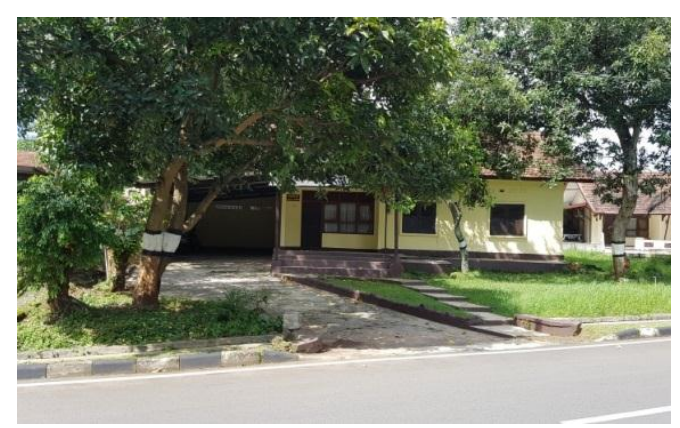

Gambar 3. Tampak depan rumah dinas Blok B 4 .

\section{Metode kualitatif}

Untuk data - data yang didapat dari kuisioner penghuni rumah dinas Blok B 4 adalah sebagai berikut :

- Menetap di Rumah Dinas sejak tahun 2016.

- Lebih nyaman tinggal karena lokasi dekat dengan akses ke markas dinas, dan juga dekat dengan lokasi tempat ibadah Gereja Kristen Protestan karena berada dalam satu asrama yang tenang untuk melakukan ibadah.

- Untuk rumah dinas juga dijaga oleh ajudan kepercayaannya yang menjabat di RS. Bhayangkara.

- Menetap dan tinggal di rumah dinas hanya saat jam dan hari pendidikan oleh jajaran Direktorat Akademik dan pada saat kegiatan dari Lemdiklat Polri.

- Tidak ada penambahan apapun untuk rumah dinas oleh Kombes Pol. Drs Fajar Setiawan, S.H., M.A., karena untuk jabatan berdinas di Akpol tidak terlalu lama dan keluarga juga tidak menetap di dalam Kota Semarang. (Lihat Gambar 3)

- Untuk intensitas penggunaan jendela digunakan secara optimal. (Lihat Gambar 3)

- Untuk kenyamanan udara dapat dirasakan cukup nyaman namun udara di dalam rumah dan teras 
rumah terasa panas, maka digunakan Air Conditioner sebagai antisipasi nya.

- Dari segi kelembaban nya terlihat ada pertumbuhan jamur pada dinding rumah namun tidak terasa lembab bagi penghuni walaupun pada kondisi seiring berlangsung nya hujan, juga disertai seringnya air hujan membasahi teras hingga masuk ke area ruang tamu melalui ventilasi dan lantai. (Lihat Gambar 3)

- Saat angin berhembus pelan maupun kencang hanya terkadang saja anginnya masuk ke area dalam rumah dan penghuni merasa nyaman dan segar karena sudah memenuhi kaedah yang berlaku bagi penghuni. (Lihat Gambar 3)

\section{Metode kuantitatif}

Untuk rumah dinas blok B 4 yang didapat dari metode kuantitatif adalah berdasarkan data - data tabel berikut : Metode kuantitatif rumah dinas Blok B 4 diukur dengan pengukuran kecepatan angin dalam " $\mathrm{m} / \mathrm{s}$ " (Lihat tabel 3), kelembaban udara dalam " $R h$ " (Lihat tabel 4), dan temperatur efektif udara dalam ukuran " $C$ ”" (Lihat tabel 5).

Tabel 3. Kecepatan angin $(\mathrm{m} / \mathrm{s})$ di rumah dinas Blok B 4.

\begin{tabular}{|l|l|l|l|}
\hline $\begin{array}{l}\text { Rumah Dinas Blok B } 4 \\
\text { Kecepatan angin }(\mathrm{m} / \mathrm{s})\end{array}$ & $\begin{array}{l}\text { Kecepatan } \\
\text { Kecepatan } \\
\begin{array}{l}\text { Waktu } \\
\mathrm{n}(W I B)\end{array} \\
(\mathrm{m} / \mathrm{s})\end{array}$ & $\begin{array}{l}\text { Kecepatan di Teras } \\
\text { Ruang } \\
\text { Keluarga } \\
(\mathrm{m} / \mathrm{s})\end{array}$ & $\begin{array}{l}\text { Angin di } \\
\text { Ruang Tidur } \\
\text { Utama }(\mathrm{m} / \mathrm{s})\end{array}$ \\
\hline $05: 00$ & $0,18 \mathrm{~m} / \mathrm{s}$ & $0.17 \mathrm{~m} / \mathrm{s}$ & $0,17 \mathrm{~m} / \mathrm{s}$ \\
\hline $06: 00$ & $0,18 \mathrm{~m} / \mathrm{s}$ & $0,17 \mathrm{~m} / \mathrm{s}$ & $0,17 \mathrm{~m} / \mathrm{s}$ \\
\hline $08: 00$ & $0,17 \mathrm{~m} / \mathrm{s}$ & $0,17 \mathrm{~m} / \mathrm{s}$ & $0,17 \mathrm{~m} / \mathrm{s}$ \\
\hline $10: 00$ & $0,17 \mathrm{~m} / \mathrm{s}$ & $0,17 \mathrm{~m} / \mathrm{s}$ & $0,17 \mathrm{~m} / \mathrm{s}$ \\
\hline $12: 00$ & $0,17 \mathrm{~m} / \mathrm{s}$ & $0,17 \mathrm{~m} / \mathrm{s}$ & $0,17 \mathrm{~m} / \mathrm{s}$ \\
\hline $14: 00$ & $0,17 \mathrm{~m} / \mathrm{s}$ & $0,16 \mathrm{~m} / \mathrm{s}$ & $0,17 \mathrm{~m} / \mathrm{s}$ \\
\hline $16: 00$ & $0,17 \mathrm{~m} / \mathrm{s}$ & $0,17 \mathrm{~m} / \mathrm{s}$ & $0,17 \mathrm{~m} / \mathrm{s}$ \\
\hline $18: 00$ & $0,17 \mathrm{~m} / \mathrm{s}$ & $0,17 \mathrm{~m} / \mathrm{s}$ & $0,16 \mathrm{~m} / \mathrm{s}$ \\
\hline $20: 00$ & $0,17 \mathrm{~m} / \mathrm{s}$ & $0,17 \mathrm{~m} / \mathrm{s}$ & $0,16 \mathrm{~m} / \mathrm{s}$ \\
\hline $22: 00$ & $0,16 \mathrm{~m} / \mathrm{s}$ & $0,16 \mathrm{~m} / \mathrm{s}$ & $0,16 \mathrm{~m} / \mathrm{s}$ \\
\hline
\end{tabular}

Tabel 4. Kelembaban udara $(R h)$ di rumah dinas Blok B 4

\begin{tabular}{|l|l|l|l|}
\hline \multicolumn{4}{|l|}{$\begin{array}{l}\text { Rumah Dinas Blok B 4 } \\
\text { Kelembaban udara }(R h)\end{array}$} \\
\hline $\begin{array}{l}\text { Waktu } \\
\text { Pengukura } \\
\text { n (WIB) }\end{array}$ & $\begin{array}{l}\text { Kelembaban } \\
\text { udara di Teras } \\
(R h)\end{array}$ & $\begin{array}{l}\text { Kelembaban } \\
\text { udara di } \\
\text { Ruang } \\
\text { Keluarga }(R h)\end{array}$ & $\begin{array}{l}\text { Kelembaban } \\
\text { udara di Ruang } \\
\text { Tidur Utama } \\
(R h)\end{array}$ \\
\hline $05: 00$ & 77,2 & 77,4 & 78,4 \\
\hline $06: 00$ & 73,5 & 73,5 & 72,7 \\
\hline $08: 00$ & 65 & 65 & 65 \\
\hline $10: 00$ & 54,5 & 54,5 & 54,5 \\
\hline $12: 00$ & 44,2 & 46,2 & 48,4 \\
\hline $14: 00$ & 50,6 & 51,6 & 51,6 \\
\hline $16: 00$ & 55 & 55 & 54,7 \\
\hline $18: 00$ & 71,2 & 70,2 & 69,4 \\
\hline $20: 00$ & 75,5 & 75,5 & 77,5 \\
\hline
\end{tabular}

\begin{tabular}{|l|l|l|l|}
\hline $22: 00$ & 78,4 & 80,5 & 80,5 \\
\hline Rata- Rata & 64,5 & 64,9 & 65,3 \\
\hline
\end{tabular}

Tabel 5. Temperatur Efektif Udara $\left({ }^{0} C\right)$ di rumah dinas Blok B 4.

\begin{tabular}{|l|l|l|l|}
\hline \multicolumn{4}{|l|}{$\begin{array}{l}\text { Rumah Dinas Blok B 4 } \\
\text { Temperatur Efektif Udara }\left({ }^{\circ} \mathrm{C}\right) .\end{array}$} \\
\hline $\begin{array}{l}\text { Waktu } \\
\text { Pengukura } \\
\mathrm{n}(\text { WIB) }\end{array}$ & $\begin{array}{l}\text { Temperatur } \\
\text { Udara di } \\
\text { Teras }\left({ }^{\circ} \mathrm{C}\right)\end{array}$ & $\begin{array}{l}\text { Temperatur } \\
\text { Udara di } \\
\text { Ruang } \\
\text { Keluarga } \\
\left({ }^{0} \mathrm{C}\right)\end{array}$ & $\begin{array}{l}\text { Temperatur } \\
\text { Udara di Ruang } \\
\text { Tidur Utama } \\
\left({ }^{\circ} \mathrm{C}\right)\end{array}$ \\
\hline $05: 00$ & 25,2 & 24,2 & 25,2 \\
\hline $06: 00$ & 26,3 & 25,3 & 25 \\
\hline $08: 00$ & 26,1 & 25,4 & 25,5 \\
\hline $10: 00$ & 25,5 & 25,7 & 25,9 \\
\hline $12: 00$ & 26,2 & 25,8 & 25,9 \\
\hline $14: 00$ & 26 & 26,1 & 26 \\
\hline $16: 00$ & 25,6 & 26,1 & 25,7 \\
\hline $18: 00$ & 26,1 & 25,5 & 26,1 \\
\hline $20: 00$ & 26 & 25,7 & 25,3 \\
\hline 22:00 & 25,2 & 25,3 & 25,6 \\
\hline Rata - Rata & 25,8 & 25,5 & 25,6 \\
\hline
\end{tabular}

\section{B. Rumah Dinas Blok B 27}

Rumah Dinas Blok B 27 adalah rumah dinas yang terletak di Jalan Bayam, walaupun rumah dinas ini memiliki nama Blok yang sama dengan rumah dinas Blok B 4, namun rumah ini tidak terletak pada posisi yang berbeda dengan JL. KS. Tubun, dan para pengunjung harus berputar terlebih awal mengitari JL. K.S Tubun dan melewati JL. Wortel agar dapat mengunjungi rumah dinas Blok B 27 ini. Rumah blok B 27 ini posisi terletak berbentuk kantong melingkar di JL. Wortel (Lihat Gambar 2).

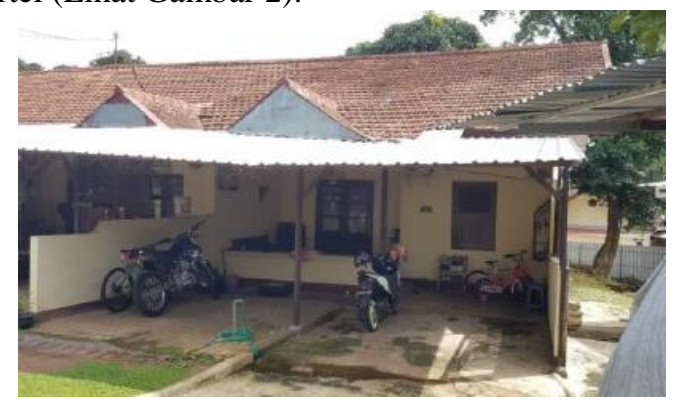

Gambar 4 Tampak depan Rumah Dinas Blok B 27.

\section{Metode kualitatif}

- Menggunakan dan menetap di rumah dinas Akpol terhitung mulai tanggal 15 Desember 2006.

- Rumah dinas di Akpol digunakan karena lebih fleksibel untuk ke lokasi area bagian Renmin dan juga lebih terjangkau harganya.

- Tempat tinggal asli berada di Provinsi Jawa Tengah dan jauh dari markas Lemdiklat Polri - Akpol, maka digunakan rumah dinas agar lebih fleksibel ke area dinas Renmin. 
- Untuk intesintas jendela sering digunakan dan dapat dirasakan cukup lebar (Lihat Gambar 4).

- Pada siang hari kondisi rumah tidak dirasakan panas saat menggunakan AC, namun udara terasa sangat panas apabila AC tidak digunakan.

- Pada dinding rumah dapat dirasakan basah serta terlihat jamur yang tumbuh dan udara juga terasa lembab pada area dalam rumah (Lihat Gambar 4).

- Air hujan dapat diantisipasi dan tidak masuk ke dalam area rumah karena ada penambahan atap teras (Lihat Gambar 4).

- Untuk kenyamanan dari hembusan angin alam dapat terasa nyaman dan membuat segar namun saat menjelang maghrib banyak nyamuk kebun yang datang karena kondisi alam perkebunan yang dijadikan sebagai sarang nyamuk kebun. (Lihat Gambar 4).

\section{Metode kuantitatif}

Untuk rumah dinas blok B 4 yang didapat dari metode kuantitatif adalah berdasarkan data - data tabel berikut : Metode kuantitatif rumah dinas Blok B 4 diukur dengan pengukuran kecepatan angin dalam " $\mathrm{m} / \mathrm{s}$ " (Lihat tabel 6), kelembaban udara dalam " $R h$ " (Lihat tabel 7), dan temperatur efektif udara dalam ukuran " ${ }^{\circ} \mathrm{C}$ ” (Lihat tabel 8).

Tabel 6. Kecepatan angin (m/s) di rumah dinas Blok B 27.

\begin{tabular}{|l|l|l|l|}
\hline \multicolumn{4}{|l|}{$\begin{array}{l}\text { Rumah Dinas Blok B 27 } \\
\text { Kecepatan angin }(\mathrm{m} / \mathrm{s})\end{array}$} \\
\hline $\begin{array}{l}\text { Waktu } \\
\begin{array}{l}\text { Pengukura } \\
\text { n (WIB) }\end{array}\end{array}$ & $\begin{array}{l}\text { Kecepatan } \\
\text { Angin di Teras } \\
(\mathrm{m} / \mathrm{s})\end{array}$ & $\begin{array}{l}\text { Kecepatan } \\
\text { Angin di } \\
\text { Ruang } \\
\text { Keluarga } \\
(\mathrm{m} / \mathrm{s})\end{array}$ & $\begin{array}{l}\text { Kecepatan } \\
\text { Angin di } \\
\text { Ruang Tidur } \\
\text { Utama }(\mathrm{m} / \mathrm{s})\end{array}$ \\
\hline $05: 00$ & $0,17 \mathrm{~m} / \mathrm{s}$ & $0.17 \mathrm{~m} / \mathrm{s}$ & $0,17 \mathrm{~m} / \mathrm{s}$ \\
\hline $06: 00$ & $0,18 \mathrm{~m} / \mathrm{s}$ & $0,17 \mathrm{~m} / \mathrm{s}$ & $0,17 \mathrm{~m} / \mathrm{s}$ \\
\hline $08: 00$ & $0,18 \mathrm{~m} / \mathrm{s}$ & $0,17 \mathrm{~m} / \mathrm{s}$ & $0,17 \mathrm{~m} / \mathrm{s}$ \\
\hline $10: 00$ & $0,17 \mathrm{~m} / \mathrm{s}$ & $0,17 \mathrm{~m} / \mathrm{s}$ & $0,17 \mathrm{~m} / \mathrm{s}$ \\
\hline $12: 00$ & $0,17 \mathrm{~m} / \mathrm{s}$ & $0,17 \mathrm{~m} / \mathrm{s}$ & $0,17 \mathrm{~m} / \mathrm{s}$ \\
\hline $14: 00$ & $0,17 \mathrm{~m} / \mathrm{s}$ & $0,16 \mathrm{~m} / \mathrm{s}$ & $0,17 \mathrm{~m} / \mathrm{s}$ \\
\hline $16: 00$ & $0,17 \mathrm{~m} / \mathrm{s}$ & $0,17 \mathrm{~m} / \mathrm{s}$ & $0,17 \mathrm{~m} / \mathrm{s}$ \\
\hline $18: 00$ & $0,17 \mathrm{~m} / \mathrm{s}$ & $0,16 \mathrm{~m} / \mathrm{s}$ & $0,17 \mathrm{~m} / \mathrm{s}$ \\
\hline $20: 00$ & $0,17 \mathrm{~m} / \mathrm{s}$ & $0,16 \mathrm{~m} / \mathrm{s}$ & $0,16 \mathrm{~m} / \mathrm{s}$ \\
\hline $22: 00$ & $0,17 \mathrm{~m} / \mathrm{s}$ & $0,16 \mathrm{~m} / \mathrm{s}$ & $0,16 \mathrm{~m} / \mathrm{s}$ \\
\hline
\end{tabular}

Tabel 7. Kelembaban udara (Rh) di rumah dinas Blok B 27

\begin{tabular}{|l|l|l|l|}
\hline \multicolumn{4}{|l|}{$\begin{array}{l}\text { Rumah Dinas Blok B 27 } \\
\text { Kelembaban udara }(R h)\end{array}$} \\
\hline $\begin{array}{l}\text { Waktu } \\
\begin{array}{l}\text { Pengukura } \\
\text { n (WIB) }\end{array}\end{array}$ & $\begin{array}{l}\text { Kelembaban } \\
\text { udara di Teras } \\
(R h)\end{array}$ & $\begin{array}{l}\text { Kelembaban } \\
\text { udara di } \\
\text { Ruang } \\
\text { Keluarga }(R h)\end{array}$ & $\begin{array}{l}\text { Kelembaban } \\
\text { udara di Ruang } \\
\text { Tidur Utama } \\
(R h)\end{array}$ \\
\hline $05: 00$ & 78,6 & 78,6 & 79,5 \\
\hline $06: 00$ & 73,5 & 73,5 & 72,8 \\
\hline $08: 00$ & 66,8 & 66,8 & 66,8 \\
\hline $10: 00$ & 54 & 54 & 54,5 \\
\hline $12: 00$ & 47,5 & 47,5 & 45,7 \\
\hline
\end{tabular}

\begin{tabular}{|l|l|l|l|}
\hline $14: 00$ & 50,5 & 50,5 & 49,7 \\
\hline $16: 00$ & 56 & 56 & 49,7 \\
\hline $18: 00$ & 70,2 & 71,4 & 55,5 \\
\hline $20: 00$ & 73,5 & 78,5 & 68,5 \\
\hline $22: 00$ & 79,6 & 78,5 & 79,5 \\
\hline Rata- Rata & 65,0 & 65,5 & 65,7 \\
\hline
\end{tabular}

Tabel 8. Temperatur Udara $\left({ }^{0} \mathrm{C}\right)$ di rumah dinas Blok B 27.

\begin{tabular}{|l|l|l|l|}
\hline \multicolumn{4}{|l|}{$\begin{array}{l}\text { Rumah Dinas Blok B } 27 \\
\text { Temperatur Efektif Udara }\left({ }^{\circ} \mathrm{C}\right) .\end{array}$} \\
\hline $\begin{array}{l}\text { Waktu } \\
\text { Pengukura } \\
\text { (WIB) }\end{array}$ & $\begin{array}{l}\text { Temperatur } \\
\text { Udara di } \\
\text { Teras }\left({ }^{\circ} \mathrm{C}\right)\end{array}$ & $\begin{array}{l}\text { Temperatur } \\
\text { Udara di } \\
\text { Ruang } \\
\text { Keluarga } \\
\left.{ }^{0} \mathrm{C}\right)\end{array}$ & $\begin{array}{l}\text { Temperatur } \\
\text { Udara di Ruang } \\
\text { Tidur Utama } \\
\left({ }^{\circ} \mathrm{C}\right)\end{array}$ \\
\hline $05: 00$ & 25,4 & 24,5 & 24,4 \\
\hline $06: 00$ & 25,3 & 25,1 & 25 \\
\hline $08: 00$ & 26,1 & 25,3 & 25,9 \\
\hline $10: 00$ & 25,5 & 25,6 & 26,1 \\
\hline $12: 00$ & 26,2 & 26,2 & 26,1 \\
\hline 14:00 & 26 & 26,2 & 26,1 \\
\hline $16: 00$ & 25,6 & 25,8 & 25,9 \\
\hline $18: 00$ & 26,1 & 26,2 & 26,2 \\
\hline $20: 00$ & 26 & 25,8 & 25,3 \\
\hline 22:00 & 25,2 & 25,1 & 25,6 \\
\hline Rata - Rata & 25,8 & 25,6 & 25,7 \\
\hline
\end{tabular}

\section{Rumah Dinas Blok C}

Rumah Dinas Blok $\mathrm{C}$ adalah rumah dinas yang berada pada area yang berseberangan dengan rumah dinas Blok B dan posisi juga berada pada JL. K.S. Tubun. Untuk rumah dinas dari Blok $\mathrm{C}$ yang dijadikan sampel hanya satu unit yaitu rumah dinas Blok C 2. (Lihat Gambar 5)

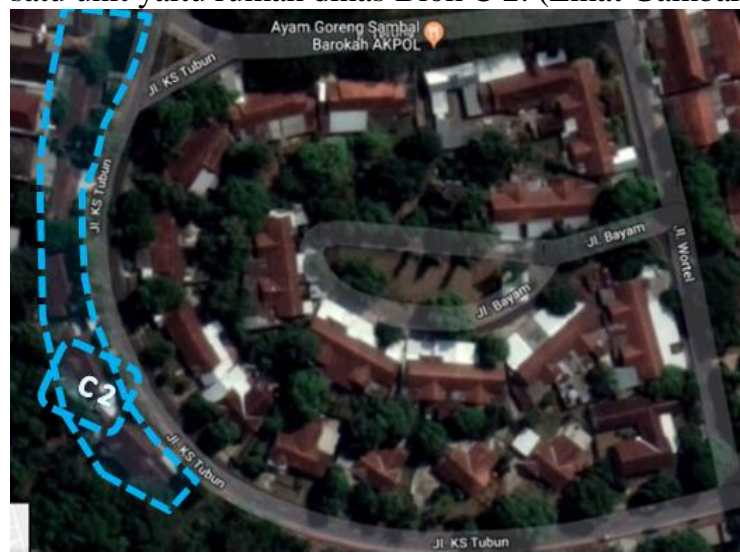

Gambar 5. Tampak Atas Rumah Dinas Blok C 2.

\subsection{Rumah Dinas Blok C 2}

Rumah dinas Blok C 2 adalah rumah dinas yang terletak persis di Jalan K.S. Tubun dan posisinya terletak agak menjorok ke arah bawah dari jalan utama itu sendiri (Lihat Gambar 5). Berikut adalah data - data yang didapat dari penghuni rumah dinas Blok $\mathrm{C} 2$. 


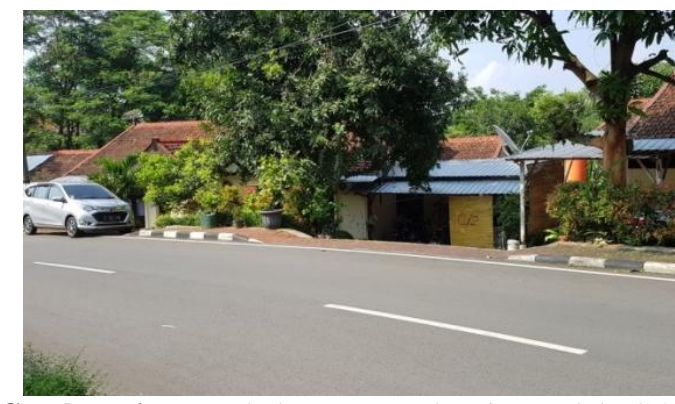

Gambar 6. Tampak depan Rumah Dinas Blok C 2.

\section{Metode kualitatif}

- Menggunakan dan menetap di rumah dinas Akpol sejak Januari 2010.

- Rumah dinas di Akpol digunakan karena lebih fleksibel untuk ke lokasi area markas bagian Direktorat Akademik.

- Beliau lebih sering menjabat di jajaran satuan Polda Jawa Tengah dan Lemdiklat Polri - Akpol karena lebih dekat dengan keluarga besar beserta tempat tinggal asli berada di Provinsi Jawa Tengah dan tidak terlalu jauh dari markas Lemdiklat Polri Akpol, maka digunakan rumah dinas agar lebih fleksibel ke area dinas Direktorat Akademik.

- Untuk intensitas jendela sering digunakan, jendela sudah dikatakan cukup lebar dan pengaplikasian AC dirasakan nyaman dan sering diaktifkan, namun saat tidak menggunakan AC, udara terasa sangat panas menjelang siang hari menuju sore hari. (Lihat Gambar 6)

- Untuk dinding rumah tidak ada jamur yang tumbuh, dan kondisi dalam rumah terasa sedikit lembab dan area dalam rumah tidak ada hempasan air hujan sama sekali. (Lihat Gambar 6)

- Untuk air movement yang memasuki rumah hanya terkadang saja terjadi, dan terasa nyaman dan segar di dalam ruangan serta membuat penghuni merasa nyaman. Tetapi itu belum cukup dan belum memenuhi standar kaedah yang berlaku bagi penghuni. (Lihat Gambar 6)

- Kondisi lingkungan seperti rumah dinas yang lainnya, banyak serangan nyamuk saat maghrib dan membuat gelisah keluarga.

\section{Metode kuantitatif}

Untuk rumah dinas blok C 2 yang didapat dari metode kuantitatif adalah berdasarkan data - data tabel berikut : Metode kuantitatif rumah dinas Blok $\mathrm{C} 2$ diukur dengan pengukuran kecepatan angin dalam " $\mathrm{m} / \mathrm{s}$ " (Lihat tabel 9), kelembaban udara dalam " $R h$ " (Lihat tabel 10), dan temperatur efektif udara dalam ukuran " ${ }^{\circ} \mathrm{C}$ " (Lihat tabel $11)$.
Tabel 9. Kecepatan angin $(\mathrm{m} / \mathrm{s})$ di rumah dinas Blok C 2

\begin{tabular}{|l|l|l|l|}
\hline $\begin{array}{l}\text { Rumah Dinas Blok C } 2 \\
\text { Kecepatan angin }(\mathrm{m} / \mathrm{s})\end{array}$ \\
\hline $\begin{array}{l}\text { Waktu } \\
\begin{array}{l}\text { Pengukura } \\
\text { n (WIB) }\end{array}\end{array}$ & $\begin{array}{l}\text { Kecepatan } \\
\text { Angin di Teras } \\
(\mathrm{m} / \mathrm{s})\end{array}$ & $\begin{array}{l}\text { Kecepatan } \\
\text { Angin di } \\
\text { Ruang } \\
\text { Keluarga } \\
(\mathrm{m} / \mathrm{s})\end{array}$ & $\begin{array}{l}\text { Kecepatan } \\
\text { Angin di } \\
\text { Ruang Tidur } \\
\text { Utama }(\mathrm{m} / \mathrm{s})\end{array}$ \\
\hline $05: 00$ & $0,17 \mathrm{~m} / \mathrm{s}$ & $0.16 \mathrm{~m} / \mathrm{s}$ & $0,16 \mathrm{~m} / \mathrm{s}$ \\
\hline $06: 00$ & $0,17 \mathrm{~m} / \mathrm{s}$ & $0,16 \mathrm{~m} / \mathrm{s}$ & $0,16 \mathrm{~m} / \mathrm{s}$ \\
\hline $08: 00$ & $0,17 \mathrm{~m} / \mathrm{s}$ & $0,17 \mathrm{~m} / \mathrm{s}$ & $0,17 \mathrm{~m} / \mathrm{s}$ \\
\hline $10: 00$ & $0,17 \mathrm{~m} / \mathrm{s}$ & $0,17 \mathrm{~m} / \mathrm{s}$ & $0,17 \mathrm{~m} / \mathrm{s}$ \\
\hline $12: 00$ & $0,17 \mathrm{~m} / \mathrm{s}$ & $0,17 \mathrm{~m} / \mathrm{s}$ & $0,17 \mathrm{~m} / \mathrm{s}$ \\
\hline $14: 00$ & $0,17 \mathrm{~m} / \mathrm{s}$ & $0,16 \mathrm{~m} / \mathrm{s}$ & $0,17 \mathrm{~m} / \mathrm{s}$ \\
\hline $16: 00$ & $0,17 \mathrm{~m} / \mathrm{s}$ & $0,17 \mathrm{~m} / \mathrm{s}$ & $0,17 \mathrm{~m} / \mathrm{s}$ \\
\hline $18: 00$ & $0,18 \mathrm{~m} / \mathrm{s}$ & $0,17 \mathrm{~m} / \mathrm{s}$ & $0,17 \mathrm{~m} / \mathrm{s}$ \\
\hline $20: 00$ & $0,18 \mathrm{~m} / \mathrm{s}$ & $0,17 \mathrm{~m} / \mathrm{s}$ & $0,16 \mathrm{~m} / \mathrm{s}$ \\
\hline $22: 00$ & $0,17 \mathrm{~m} / \mathrm{s}$ & $0,17 \mathrm{~m} / \mathrm{s}$ & $0,16 \mathrm{~m} / \mathrm{s}$ \\
\hline
\end{tabular}

Tabel 10. Kelembaban udara (Rh) di rumah dinas Blok $\mathrm{C} 2$

\begin{tabular}{|l|l|l|l|}
\hline $\begin{array}{l}\text { Rumah Dinas Blok C } 2 \\
\text { Kelembaban udara }(R h)\end{array}$ \\
\hline $\begin{array}{l}\text { Waktu } \\
\begin{array}{l}\text { Pengukura } \\
\text { n (WIB) }\end{array}\end{array}$ & $\begin{array}{l}\text { Kelembaban } \\
\text { udara di Teras } \\
(R h)\end{array}$ & $\begin{array}{l}\text { Kelembaban } \\
\text { udara di } \\
\text { Ruang } \\
\text { Keluarga }(R h)\end{array}$ & $\begin{array}{l}\text { Kelembaban } \\
\text { udara di Ruang } \\
\text { Tidur Utama } \\
(R h)\end{array}$ \\
\hline $05: 00$ & 78,6 & 78,6 & 78,6 \\
\hline $06: 00$ & 73,5 & 73,5 & 72,7 \\
\hline $08: 00$ & 66,8 & 66,8 & 66,8 \\
\hline $10: 00$ & 54,5 & 54,5 & 54,5 \\
\hline $12: 00$ & 43,7 & 45,7 & 45,7 \\
\hline $14: 00$ & 49,7 & 49,7 & 49,7 \\
\hline $16: 00$ & 55,5 & 55,5 & 55,5 \\
\hline $18: 00$ & 68,5 & 68,5 & 68,5 \\
\hline $20: 00$ & 73,5 & 77,5 & 77,5 \\
\hline 22:00 & 78,6 & 80,5 & 80,5 \\
\hline Rata- Rata & 64,3 & 65,1 & 65,0 \\
\hline
\end{tabular}

Tabel 11. Temperatur Udara $\left({ }^{0} \mathrm{C}\right)$ di rumah dinas Blok $\mathrm{C} 2$.

\begin{tabular}{|l|l|l|l|}
\hline \multicolumn{4}{|l|}{$\begin{array}{l}\text { Rumah Dinas Blok C } 2 \\
\text { Temperatur Udara }\left({ }^{\circ} C\right) .\end{array}$} \\
\hline $\begin{array}{l}\text { Waktu } \\
\text { Pengukura } \\
\mathrm{n}(\text { WIB) }\end{array}$ & $\begin{array}{l}\text { Temperatur } \\
\text { Udara di } \\
\text { Teras }\left({ }^{\circ} C\right)\end{array}$ & $\begin{array}{l}\text { Temperatur } \\
\text { Udara di } \\
\text { Ruang } \\
\text { Keluarga } \\
\left.{ }^{0} C\right)\end{array}$ & $\begin{array}{l}\text { Temperatur } \\
\text { Udara di Ruang } \\
\text { Tidur Utama } \\
\left({ }^{\circ} C\right)\end{array}$ \\
\hline $05: 00$ & 25,4 & 25,7 & 25,6 \\
\hline $06: 00$ & 26,3 & 25,4 & 25,2 \\
\hline $08: 00$ & 27,3 & 25,5 & 25,9 \\
\hline $10: 00$ & 26 & 25,7 & 25,9 \\
\hline $12: 00$ & 25,9 & 25,6 & 25,5 \\
\hline $14: 00$ & 26 & 26,1 & 26 \\
\hline $16: 00$ & 25,7 & 26,1 & 25,8 \\
\hline $18: 00$ & 26 & 25,8 & 26 \\
\hline $20: 00$ & 25,7 & 25,9 & 25,3 \\
\hline $22: 00$ & 25,2 & 25 & 25,4 \\
\hline Rata - Rata & 26,0 & 25,7 & 25,7 \\
\hline
\end{tabular}

\section{Rumah Dinas Blok E}

Rumah Dinas Blok E adalah rumah dinas yang berada pada Jalan Bougenville. Area rumah dinas ini terletak 
pada sebelah utara dari kawasan Akademi Kepolisian dan berbatasan dengan tembok pembatas dari kawasan Akademi Kepolisian dan juga Jalan Papandayan yang merupakan jalan umum. Untuk rumah dinas di area Blok E yang dijadikan sampel adalah rumah dinas Blok E 12. (Lihat Gambar 7)

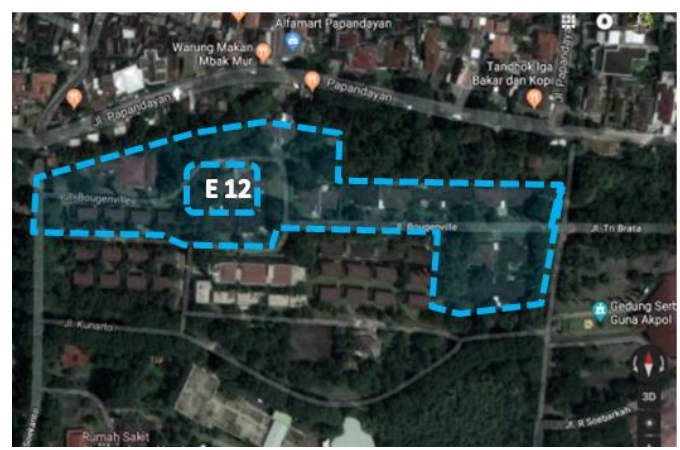

Gambar 7. Tampak Atas Rumah Dinas Blok E 12.

\subsection{Rumah Dinas Blok E 12}

Rumah Dinas Blok E 12 adalah rumah dinas yang berbatasan tepat dengan tembok pembatas dari Jalan Bougenville dengan Jalan Papandayan. Posisi rumah dinas ini berada di sebelah utara dari kawasan Akademi Kepolisian (Lihat Gambar 7). Berikut ini adalah data data yang didapat dari penghuni rumah dinas Blok E 12 .

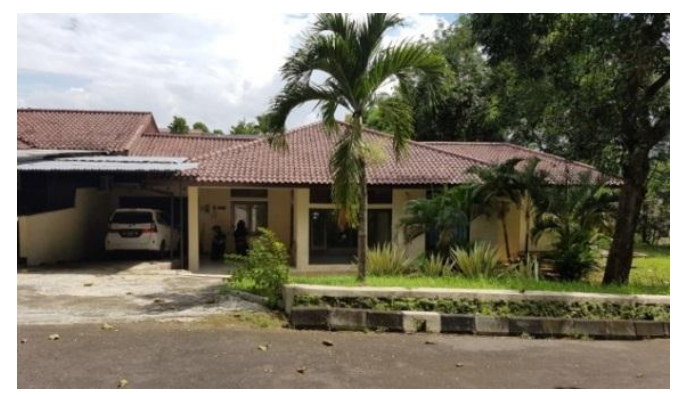

Gambar 8. Tampak depan Rumah Dinas Blok E 12.

- Menggunakan dan menetap di rumah dinas Akpol sejak tahun 2010

- Rumah dinas di Akpol digunakan karena lebih fleksibel dan nyaman untuk ke lokasi area markas bagian Direktorat Bintarlat, Korbintarsis karena beliau bertugas sebagai Komadan Pleton (Danton).

- Beliau lebih sering menjabat di jajaran satuan Polda Jawa Tengah dan Lemdiklat Polri - Akpol karena harga lebih terjangkau dan kualitas lebih optimal, karena beliau asli Jawa Tengah dan area juga dekat dengan Direktorat Bintarlat.

- Untuk intensitas pengaplikasian jendela cukup sering digunakan dan jendela rumah dapat dikatakan cukup lebar dan siang hari rumah dapat dikatakan nyaman karena terhindar dari panas, namun AC sering digunakan karena sudah terbiasa walaupun tidak ada rasa panas yang terik saat siang dan menjelanh sore hari. (Lihat Gambar 8)

- Dari segi kelembaban dirasakan tidak ada kelembaban dan tidak ada percikkan air hujan yang membasahi ruang tamu, dan AC yang diaplikasikan juga tidak menghasilkan kelembaban disekitar nya. (Lihat Gambar 8)

- Rumah dinas ini juga sering didatangi nyamuk kebun saat maghrib, namun bagi penghuni kondisi udara ini sudah dirasakan sebagai sirkulasi udara yang memenuhi standar dan kaedah yang berlaku.

\section{Metode kuantitatif}

Untuk rumah dinas blok E 12 yang didapat dari metode kuantitatif adalah berdasarkan data - data tabel berikut : Metode kuantitatif rumah dinas Blok E 12 diukur dengan pengukuran kecepatan angin dalam " $\mathrm{m} / \mathrm{s}$ " (Lihat tabel 12), kelembaban udara dalam " $R h$ " (Lihat tabel 13), dan temperatur efektif udara dalam ukuran " ${ }^{\prime 0}$ ”, (Lihat tabel 14).

Tabel 12. Kecepatan angin (m/s) di rumah dinas Blok E 12.

\begin{tabular}{|l|l|l|l|}
\hline \multicolumn{4}{|l|}{$\begin{array}{l}\text { Rumah Dinas Blok E 12 } \\
\text { Kecepatan angin }(\mathrm{m} / \mathrm{s})\end{array}$} \\
\hline $\begin{array}{l}\text { Waktu } \\
\begin{array}{l}\text { Pengukura } \\
\text { n (WIB) }\end{array}\end{array}$ & $\begin{array}{l}\text { Kecepatan } \\
\text { Angin di Teras } \\
(\mathrm{m} / \mathrm{s})\end{array}$ & $\begin{array}{l}\text { Kecepatan } \\
\text { Angin di } \\
\text { Ruang } \\
\text { Keluarga } \\
(\mathrm{m} / \mathrm{s})\end{array}$ & $\begin{array}{l}\text { Kecepatan } \\
\text { Angin di } \\
\text { Ruang Tidur } \\
\text { Utama }(\mathrm{m} / \mathrm{s})\end{array}$ \\
\hline $05: 00$ & $0,17 \mathrm{~m} / \mathrm{s}$ & $0.16 \mathrm{~m} / \mathrm{s}$ & $0,16 \mathrm{~m} / \mathrm{s}$ \\
\hline $06: 00$ & $0,17 \mathrm{~m} / \mathrm{s}$ & $0,16 \mathrm{~m} / \mathrm{s}$ & $0,17 \mathrm{~m} / \mathrm{s}$ \\
\hline $08: 00$ & $0,17 \mathrm{~m} / \mathrm{s}$ & $0,17 \mathrm{~m} / \mathrm{s}$ & $0,17 \mathrm{~m} / \mathrm{s}$ \\
\hline $10: 00$ & $0,18 \mathrm{~m} / \mathrm{s}$ & $0,17 \mathrm{~m} / \mathrm{s}$ & $0,17 \mathrm{~m} / \mathrm{s}$ \\
\hline $12: 00$ & $0,17 \mathrm{~m} / \mathrm{s}$ & $0,17 \mathrm{~m} / \mathrm{s}$ & $0,17 \mathrm{~m} / \mathrm{s}$ \\
\hline $14: 00$ & $0,18 \mathrm{~m} / \mathrm{s}$ & $0,16 \mathrm{~m} / \mathrm{s}$ & $0,16 \mathrm{~m} / \mathrm{s}$ \\
\hline $16: 00$ & $0,17 \mathrm{~m} / \mathrm{s}$ & $0,17 \mathrm{~m} / \mathrm{s}$ & $0,17 \mathrm{~m} / \mathrm{s}$ \\
\hline $18: 00$ & $0,17 \mathrm{~m} / \mathrm{s}$ & $0,17 \mathrm{~m} / \mathrm{s}$ & $0,17 \mathrm{~m} / \mathrm{s}$ \\
\hline $20: 00$ & $0,17 \mathrm{~m} / \mathrm{s}$ & $0,17 \mathrm{~m} / \mathrm{s}$ & $0,17 \mathrm{~m} / \mathrm{s}$ \\
\hline $22: 00$ & $0,17 \mathrm{~m} / \mathrm{s}$ & $0,17 \mathrm{~m} / \mathrm{s}$ & $0,16 \mathrm{~m} / \mathrm{s}$ \\
\hline
\end{tabular}

Tabel 13. Kelembaban udara (Rh) di rumah dinas Blok E 12.

\begin{tabular}{|l|l|l|l|}
\hline \multicolumn{4}{|l|}{$\begin{array}{l}\text { Rumah Dinas Blok E 12 } \\
\text { Kelembaban udara }(R h)\end{array}$} \\
\hline $\begin{array}{l}\text { Waktu } \\
\begin{array}{l}\text { Pengukura } \\
\text { n (WIB) }\end{array}\end{array}$ & $\begin{array}{l}\text { Kelembaban } \\
\text { udara di Teras } \\
(R h)\end{array}$ & $\begin{array}{l}\text { Kelembaban } \\
\text { udara di } \\
\text { Ruang } \\
\text { Keluarga }(R h)\end{array}$ & $\begin{array}{l}\text { Kelembaban } \\
\text { udara di Ruang } \\
\text { Tidur Utama } \\
(R h)\end{array}$ \\
\hline $05: 00$ & 78,6 & 78,6 & 78,3 \\
\hline $06: 00$ & 74,0 & 74,0 & 73,0 \\
\hline $08: 00$ & 67 & 67 & 67 \\
\hline $10: 00$ & 53,5 & 53,5 & 53,5 \\
\hline $12: 00$ & 44,5 & 44,5 & 49,5 \\
\hline $14: 00$ & 48,5 & 48,5 & 48,5 \\
\hline $16: 00$ & 57,5 & 57,5 & 57,5 \\
\hline $18: 00$ & 69,7 & 69,7 & 69,7 \\
\hline 20:00 & 76 & 76 & 76 \\
\hline 22:00 & 78,6 & 81,5 & 81,5 \\
\hline Rata- Rata & 64,8 & 65,1 & 65,5 \\
\hline
\end{tabular}


Tabel 14. Temperatur Udara $\left({ }^{0} \mathrm{C}\right)$ di rumah dinas Blok E 12

\begin{tabular}{|l|l|l|l|}
\hline \multicolumn{4}{|l|}{$\begin{array}{l}\text { Rumah Dinas Blok E 12 } \\
\text { Temperatur Udara }\left({ }^{\circ} C\right) .\end{array}$} \\
\hline $\begin{array}{l}\text { Waktu } \\
\text { Pengukura } \\
\text { (WIB) }\end{array}$ & $\begin{array}{l}\text { Temperatur } \\
\text { Udara di } \\
\text { Teras }\left({ }^{\circ} \mathrm{C}\right)\end{array}$ & $\begin{array}{l}\text { Temperatur } \\
\text { Udara di } \\
\text { Ruang } \\
\text { Keluarga } \\
\left.{ }^{0} \mathrm{C}\right)\end{array}$ & $\begin{array}{l}\text { Temperatur } \\
\text { Udara di Ruang } \\
\text { Tidur Utama } \\
\left({ }^{\circ} \mathrm{C}\right)\end{array}$ \\
\hline $05: 00$ & 25,5 & 25,5 & 25,2 \\
\hline $06: 00$ & 25,4 & 25,4 & 25,2 \\
\hline $08: 00$ & 25,8 & 25,8 & 25,9 \\
\hline $10: 00$ & 26,1 & 26,1 & 25,7 \\
\hline $12: 00$ & 26,1 & 26,1 & 26,1 \\
\hline $14: 00$ & 26 & 26 & 25,9 \\
\hline $16: 00$ & 26,2 & 26,2 & 26,2 \\
\hline $18: 00$ & 25,5 & 25,5 & 25,9 \\
\hline $20: 00$ & 25,8 & 25,8 & 25,2 \\
\hline $22: 00$ & 25,4 & 25,4 & 25,5 \\
\hline Rata- Rata & 25,8 & 25,8 & 25,7 \\
\hline
\end{tabular}

\section{Rumah Dinas Blok $\mathrm{H}$}

Area rumah dinas pada blok $\mathrm{H}$ terdapat banyak jumlah rumah dinas, rumah dinas yang terdapat di blok $\mathrm{H}$ juga terdapat bermacam - macam tipe. Rumah dinas ini terletak pada Jalan Duku, Jalan Nanas, Jalan Jeruk, dan Jalan Manggis (Lihat Gambar 9). Untuk lokasi rumah dinas ini berada pada sebelah selatan dari kawasan Akademi Kepolisian, berikut adalah lokasi area rumah dinas pada blok $\mathrm{H}$ yang di dambil dan data - data yang didapat dari 5 rumah dinas.

\subsection{Rumah Dinas Blok H 2}

Rumah dinas Blok H 2 adalah rumah dinas yang berada pada jalan Duku sebelah utara yang berada pada posisi sebelah utara kawasan area blok $\mathrm{H} 2$ dan menghadap ke arah utara (Lihat Gambar 9). Berikut ini adalah data data yang didapat dari rumah dinas Blok H 2.

\section{Metode kualitatif}

- Menggunakan dan menetap di rumah dinas Akpol sejak bulan Januari 1994.

- Rumah dinas di Akpol digunakan karena lebih fleksibel dan nyaman untuk ke lokasi area markas bagian Renmin.

- Beliau menggunakan rumah dinas Akpol karena dari segi harga dapat dikatakan terjangkau dan juga karena sering menjabat di jajaran Lemdiklat Polri Akpol dan Polda Jawa tengah.

- Untuk intensitas jendela sering dipakai dan jendela sudah cukup lebar namun AC tetap sering digunakan oleh beliau walaupun area ruangan sudah dapat dirasakan cukup optimal. (Lihat Gambar 9)

- Untuk kelembaban yang dirasakan beliau sangat terasa lembab namun tidak ada satupun jamur yang tumbuh saat diinvestigasi dan tidak ada air hujan yang membasahi ruangan.

- Untuk air movement hanya terasa terkadang saja gerakan angin yang masuk ke dalam rumah namun walaupun begitu tetap membuat nyaman dan segar bagi beliau, dan nyaman untuk berkonsentrasi dan beristirahat.(Lihat Gambar 9)

- Saat maghrib hanya ada beberapa nyamuk saja yang mendatangi kediaman beliau dan dapat dikatakan sedikit jumlahnya.

Sirkulasi udara bagi beliau sudah memenuhi standar dan kaedah yang berlaku.

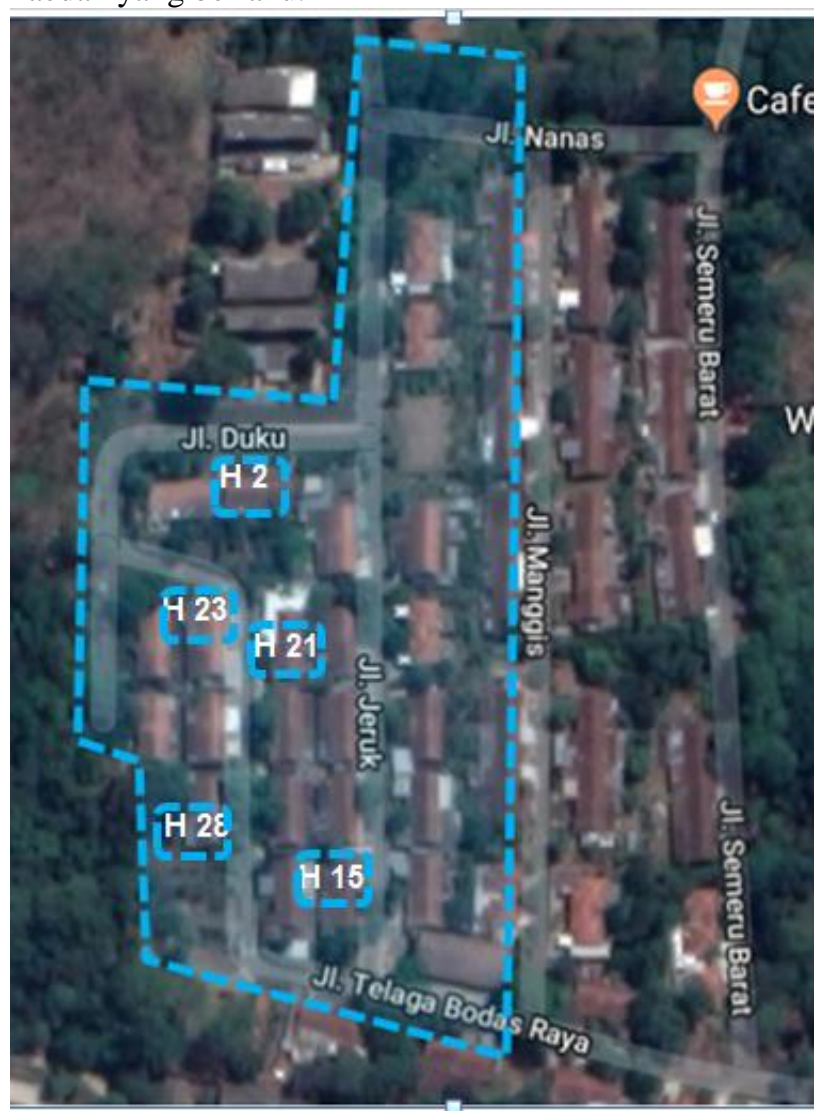

Gambar 9. Tampak atas keseluruhan Rumah Dinas Blok H.

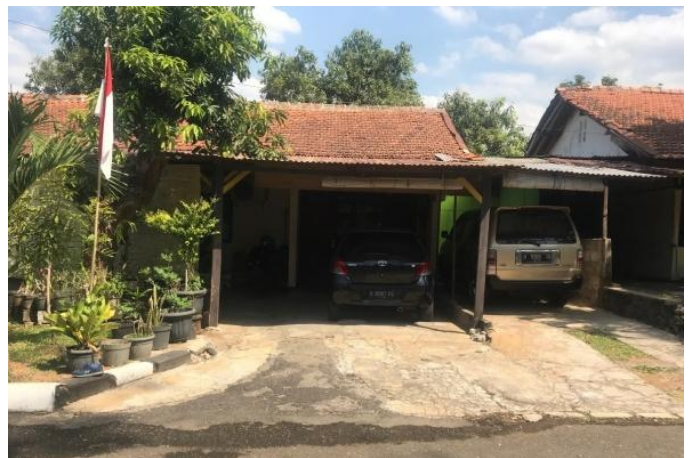

Gambar 10. Tampak depan Rumah Dinas Blok H 2.

\section{Metode kuantitatif}

Untuk rumah dinas blok $\mathrm{H} 2$ yang didapat dari metode kuantitatif adalah berdasarkan data - data tabel berikut : Metode kuantitatif rumah dinas Blok $\mathrm{H} 2$ diukur dengan pengukuran kecepatan angin dalam " $\mathrm{m} / \mathrm{s}$ " (Lihat tabel 
15), kelembaban udara dalam " $R h$ ” (Lihat tabel 16), dan temperatur efektif udara dalam ukuran " ${ }^{\circ} C$ ” (Lihat tabel 17)

Tabel 15. Kecepatan angin $(\mathrm{m} / \mathrm{s})$ di rumah dinas Blok H 2

\begin{tabular}{|l|l|l|l|}
\hline $\begin{array}{l}\text { Rumah Dinas Blok H } 2 \\
\text { Kecepatan angin }(\mathrm{m} / \mathrm{s})\end{array}$ \\
\hline $\begin{array}{l}\text { Waktu } \\
\text { Pengukura } \\
\text { (WIB) }\end{array}$ & $\begin{array}{l}\text { Kecepatan } \\
\text { Angin di Teras } \\
(\mathrm{m} / \mathrm{s})\end{array}$ & $\begin{array}{l}\text { Kecepatan } \\
\text { Angin di } \\
\text { Ruang } \\
\text { Keluarga } \\
(\mathrm{m} / \mathrm{s})\end{array}$ & $\begin{array}{l}\text { Kecepatan } \\
\text { Angin di } \\
\text { Ruang Tidur } \\
\text { Utama }(\mathrm{m} / \mathrm{s})\end{array}$ \\
\hline $05: 00$ & $0,17 \mathrm{~m} / \mathrm{s}$ & $0.16 \mathrm{~m} / \mathrm{s}$ & $0,16 \mathrm{~m} / \mathrm{s}$ \\
\hline $06: 00$ & $0,17 \mathrm{~m} / \mathrm{s}$ & $0,16 \mathrm{~m} / \mathrm{s}$ & $0,16 \mathrm{~m} / \mathrm{s}$ \\
\hline $08: 00$ & $0,17 \mathrm{~m} / \mathrm{s}$ & $0,17 \mathrm{~m} / \mathrm{s}$ & $0,17 \mathrm{~m} / \mathrm{s}$ \\
\hline $10: 00$ & $0,17 \mathrm{~m} / \mathrm{s}$ & $0,17 \mathrm{~m} / \mathrm{s}$ & $0,17 \mathrm{~m} / \mathrm{s}$ \\
\hline $12: 00$ & $0,17 \mathrm{~m} / \mathrm{s}$ & $0,17 \mathrm{~m} / \mathrm{s}$ & $0,17 \mathrm{~m} / \mathrm{s}$ \\
\hline $14: 00$ & $0,17 \mathrm{~m} / \mathrm{s}$ & $0,16 \mathrm{~m} / \mathrm{s}$ & $0,17 \mathrm{~m} / \mathrm{s}$ \\
\hline $16: 00$ & $0,17 \mathrm{~m} / \mathrm{s}$ & $0,17 \mathrm{~m} / \mathrm{s}$ & $0,17 \mathrm{~m} / \mathrm{s}$ \\
\hline $18: 00$ & $0,18 \mathrm{~m} / \mathrm{s}$ & $0,18 \mathrm{~m} / \mathrm{s}$ & $0,17 \mathrm{~m} / \mathrm{s}$ \\
\hline $20: 00$ & $0,18 \mathrm{~m} / \mathrm{s}$ & $0,17 \mathrm{~m} / \mathrm{s}$ & $0,17 \mathrm{~m} / \mathrm{s}$ \\
\hline $22: 00$ & $0,17 \mathrm{~m} / \mathrm{s}$ & $0,17 \mathrm{~m} / \mathrm{s}$ & $0,16 \mathrm{~m} / \mathrm{s}$ \\
\hline
\end{tabular}

Tabel 16. Kelembaban udara $(\mathrm{Rh})$ di rumah dinas Blok $\mathrm{H} 2$

\begin{tabular}{|c|c|c|c|}
\hline \multicolumn{4}{|c|}{$\begin{array}{l}\text { Rumah Dinas Blok H } 2 \\
\text { Kelembaban udara }(R h)\end{array}$} \\
\hline $\begin{array}{l}\text { Waktu } \\
\text { Pengukura } \\
\text { n (WIB) }\end{array}$ & $\begin{array}{l}\text { Kelembaban } \\
\text { udara di Teras } \\
(R h)\end{array}$ & $\begin{array}{l}\text { Kelembaban } \\
\text { udara di } \\
\text { Ruang } \\
\text { Keluarga }(R h)\end{array}$ & $\begin{array}{l}\text { Kelembaban } \\
\text { udara di Ruang } \\
\text { Tidur Utama } \\
(R h)\end{array}$ \\
\hline 05:00 & 77,2 & 77,2 & 76,2 \\
\hline 06:00 & 74,1 & 74,1 & 72,1 \\
\hline 08:00 & 66,8 & 66,8 & 66,8 \\
\hline 10:00 & 58,1 & 54,1 & 54,1 \\
\hline $12: 00$ & 44,2 & 44,2 & 47,2 \\
\hline 14:00 & 49,5 & 49,5 & 49,5 \\
\hline $16: 00$ & 58,1 & 58,1 & 58,1 \\
\hline $18: 00$ & 73,6 & 72,6 & 72,6 \\
\hline 20:00 & 76 & 76 & 76 \\
\hline 22:00 & 76,2 & 80,3 & 82,3 \\
\hline Rata- Rata & 65,4 & 65,3 & 65,5 \\
\hline
\end{tabular}

Tabel 17. Temperatur Udara $\left({ }^{0} \mathrm{C}\right)$ di rumah dinas Blok H 2

\begin{tabular}{|l|l|l|l|}
\hline \multicolumn{4}{|l|}{$\begin{array}{l}\text { Rumah Dinas Blok } \mathrm{H} 2 \\
\text { Temperatur Udara }\left({ }^{\circ} \mathrm{C}\right) .\end{array}$} \\
\hline $\begin{array}{l}\text { Waktu } \\
\text { Pengukura } \\
\text { n (WIB) }\end{array}$ & $\begin{array}{l}\text { Temperatur } \\
\text { Udara di } \\
\text { Teras }\left({ }^{\circ} \mathrm{C}\right)\end{array}$ & $\begin{array}{l}\text { Temperatur } \\
\text { Udara di } \\
\text { Ruang } \\
\text { Keluarga } \\
\left({ }^{\circ} \mathrm{C}\right)\end{array}$ & $\begin{array}{l}\text { Temperatur } \\
\text { Udara di Ruang } \\
\text { Tidur Utama } \\
\left({ }^{\circ} \mathrm{C}\right)\end{array}$ \\
\hline $05: 00$ & 25,7 & 25,5 & 25,3 \\
\hline $06: 00$ & 25,3 & 25,4 & 25,1 \\
\hline $08: 00$ & 25,8 & 25,3 & 25,9 \\
\hline $10: 00$ & 26,7 & 25,6 & 26 \\
\hline $12: 00$ & 25,9 & 25,3 & 25,8 \\
\hline $14: 00$ & 26,3 & 26,1 & 26 \\
\hline $16: 00$ & 26,7 & 26,5 & 26 \\
\hline $18: 00$ & 25,8 & 25,7 & 26,1 \\
\hline $20: 00$ & 26,2 & 25,8 & 25,3 \\
\hline $22: 00$ & 26,2 & 25,3 & 25,9 \\
\hline Rata- Rata & 26,1 & 25,7 & 25,8 \\
\hline
\end{tabular}

\subsection{Rumah Dinas Blok $\mathrm{H} 12$}

Rumah dinas Blok H 12 adalah rumah dinas yang berada pada jalan Jeruk. Rumah dinas ini memiliki posisi menghadap ke arah timur (Lihat Gambar 9). Berikut ini adalah data - data yang didapat dari rumah dinas Blok $\mathrm{H}$ 12.

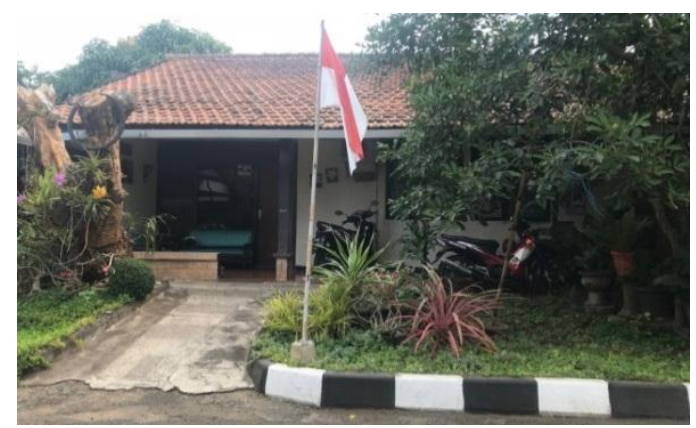

Gambar 11. Tampak depan Rumah Dinas Blok H 12.

\section{Metode kualitatif}

- Menggunakan dan menetap di rumah dinas Akpol sejak tahun 2004.

- Rumah dinas di Akpol digunakan karena lebih fleksibel dan nyaman untuk ke lokasi area markas pusat Lemdiklat Polri - Akpol.

- Beliau menggunakan rumah dinas Akpol karena dari segi harga dapat dikatakan terjangkau dan juga karena sering menjabat di jajaran Lemdiklat Polri Akpol dan Polda Jawa tengah.

- Untuk intensitas jendela sering dipakai dan jendela sudah cukup lebar namun AC hanya terkadang saja digunakan oleh beliau dan dari siang hingga menjelang sore hari tidak dirasakan panas oleh beliau. (Lihat Gambar 11)

- Untuk kelembaban yang dirasakan beliau sangat terasa tidak ada satupun jamur yang tumbuh dan tidak ada kelembaban di area rumah. (Lihat Gambar 11)

- Untuk air movement sering dirasakan angin memasuki area rumah dan membuat nyaman dan segar. (Lihat Gambar 11)

- Pada waktu maghrib jumlah nyamuk hanya sedikit yang mendatangi kediamannya.

- Dari itu semua sirkulasi udara dapat dikatakan cukup memenuhi standar kaedah yang berlaku.

\section{Metode Kuantitatif}

Untuk rumah dinas blok $\mathrm{H} 12$ yang didapat dari metode kuantitatif adalah berdasarkan data - data tabel berikut : Metode kuantitatif rumah dinas Blok H 12 diukur dengan pengukuran kecepatan angin dalam " $\mathrm{m} / \mathrm{s}$ " (Lihat tabel 18), kelembaban udara dalam " $R h$ " (Lihat tabel 19), dan temperatur efektif udara dalam ukuran ${ }^{~}{ }^{0} C$ " (Lihat tabel 20). 
Tabel 18. Kecepatan angin (m/s) di rumah dinas Blok H 12.

\begin{tabular}{|l|l|l|l|}
\hline \multicolumn{4}{|l|}{$\begin{array}{l}\text { Rumah Dinas Blok H 12 } \\
\text { Kecepatan angin }(\mathrm{m} / \mathrm{s})\end{array}$} \\
\hline $\begin{array}{l}\text { Waktu } \\
\text { Pengukura } \\
\mathrm{n}(\mathrm{WIB})\end{array}$ & $\begin{array}{l}\text { Kecepatan } \\
\text { Angin di Teras } \\
(\mathrm{m} / \mathrm{s})\end{array}$ & $\begin{array}{l}\text { Kecepatan } \\
\text { Angin di } \\
\text { Ruang } \\
\text { Keluarga } \\
(\mathrm{m} / \mathrm{s})\end{array}$ & $\begin{array}{l}\text { Kecepatan } \\
\text { Angin di } \\
\text { Ruang Tidur } \\
\text { Utama }(\mathrm{m} / \mathrm{s})\end{array}$ \\
\hline $05: 00$ & $0,17 \mathrm{~m} / \mathrm{s}$ & $0.16 \mathrm{~m} / \mathrm{s}$ & $0,16 \mathrm{~m} / \mathrm{s}$ \\
\hline $06: 00$ & $0,17 \mathrm{~m} / \mathrm{s}$ & $0,16 \mathrm{~m} / \mathrm{s}$ & $0,16 \mathrm{~m} / \mathrm{s}$ \\
\hline $08: 00$ & $0,17 \mathrm{~m} / \mathrm{s}$ & $0,17 \mathrm{~m} / \mathrm{s}$ & $0,17 \mathrm{~m} / \mathrm{s}$ \\
\hline $10: 00$ & $0,17 \mathrm{~m} / \mathrm{s}$ & $0,17 \mathrm{~m} / \mathrm{s}$ & $0,17 \mathrm{~m} / \mathrm{s}$ \\
\hline $12: 00$ & $0,17 \mathrm{~m} / \mathrm{s}$ & $0,17 \mathrm{~m} / \mathrm{s}$ & $0,17 \mathrm{~m} / \mathrm{s}$ \\
\hline $14: 00$ & $0,17 \mathrm{~m} / \mathrm{s}$ & $0,16 \mathrm{~m} / \mathrm{s}$ & $0,17 \mathrm{~m} / \mathrm{s}$ \\
\hline $16: 00$ & $0,18 \mathrm{~m} / \mathrm{s}$ & $0,17 \mathrm{~m} / \mathrm{s}$ & $0,17 \mathrm{~m} / \mathrm{s}$ \\
\hline $18: 00$ & $0,18 \mathrm{~m} / \mathrm{s}$ & $0,18 \mathrm{~m} / \mathrm{s}$ & $0,17 \mathrm{~m} / \mathrm{s}$ \\
\hline $20: 00$ & $0,18 \mathrm{~m} / \mathrm{s}$ & $0,17 \mathrm{~m} / \mathrm{s}$ & $0,17 \mathrm{~m} / \mathrm{s}$ \\
\hline $22: 00$ & $0,17 \mathrm{~m} / \mathrm{s}$ & $0,17 \mathrm{~m} / \mathrm{s}$ & $0,16 \mathrm{~m} / \mathrm{s}$ \\
\hline
\end{tabular}

Tabel 19. Kelembaban udara (Rh) di rumah dinas Blok H 12.

\begin{tabular}{|l|l|l|l|}
\hline $\begin{array}{l}\text { Rumah Dinas Blok H 12 } \\
\text { Kelembaban udara }(R h)\end{array}$ \\
\hline $\begin{array}{l}\text { Waktu } \begin{array}{l}\text { Pengukura } \\
\text { n (WIB) }\end{array} \\
\text { Kelembaban } \\
\text { udara di Teras } \\
(R h)\end{array}$ & $\begin{array}{l}\text { Kelembaban } \\
\text { udara di } \\
\text { Ruang } \\
\text { Keluarga }(R h)\end{array}$ & $\begin{array}{l}\text { Kelembaban } \\
\text { udara di Ruang } \\
\text { Tidur Utama } \\
(R h)\end{array}$ \\
\hline $05: 00$ & 78,6 & 78,6 & 78,8 \\
\hline $06: 00$ & 73,6 & 73,6 & 71,6 \\
\hline $08: 00$ & 66,8 & 66,8 & 66,8 \\
\hline $10: 00$ & 56 & 54,7 & 54,7 \\
\hline $12: 00$ & 42,5 & 46,5 & 46,5 \\
\hline $14: 00$ & 49,7 & 49,7 & 49,7 \\
\hline $16: 00$ & 56 & 56 & 56,4 \\
\hline $18: 00$ & 71,4 & 70,9 & 70,9 \\
\hline $20: 00$ & 73,5 & 75,5 & 75,5 \\
\hline 22:00 & 78,6 & 80,5 & 80,5 \\
\hline Rata- Rata & 64,7 & 65,3 & 65,1 \\
\hline
\end{tabular}

Tabel 20. Temperatur Udara $\left({ }^{0} \mathrm{C}\right)$ di rumah dinas Blok H 12

\begin{tabular}{|l|l|l|l|}
\hline $\begin{array}{l}\text { Rumah Dinas Blok } \mathrm{H} 12 \\
\text { Temperatur Udara }\left({ }^{\circ} \mathrm{C}\right) .\end{array}$ \\
\hline $\begin{array}{l}\text { Waktu } \\
\text { Pengukura } \\
\text { n (WIB) }\end{array}$ & $\begin{array}{l}\text { Temperatur } \\
\text { Udara di } \\
\text { Teras }\left({ }^{\circ} \mathrm{C}\right)\end{array}$ & $\begin{array}{l}\text { Temperatur } \\
\text { Udara di } \\
\text { Ruang } \\
\text { Keluarga } \\
\left({ }^{\circ} \mathrm{C}\right)\end{array}$ & $\begin{array}{l}\text { Temperatur } \\
\text { Udara di Ruang } \\
\text { Tidur Utama } \\
\left({ }^{\circ} \mathrm{C}\right)\end{array}$ \\
\hline $05: 00$ & 24 & 24,8 & 24,7 \\
\hline $06: 00$ & 24,7 & 25,1 & 25,1 \\
\hline $08: 00$ & 25,8 & 25,5 & 25,9 \\
\hline $10: 00$ & 26,5 & 25,7 & 26 \\
\hline $12: 00$ & 26,1 & 25,7 & 25,6 \\
\hline $14: 00$ & 26,4 & 26,1 & 26 \\
\hline $16: 00$ & 25 & 24,8 & 25,9 \\
\hline 18:00 & 24,8 & 25,6 & 25,9 \\
\hline $20: 00$ & 25 & 25,6 & 25,2 \\
\hline $22: 00$ & 25,2 & 25 & 25,8 \\
\hline Rata- Rata & 25,4 & 25,4 & 25,6 \\
\hline
\end{tabular}

\subsection{Rumah Dinas Blok H 15}

Rumah dinas Blok H 15 adalah rumah dinas yang berada pada jalan Duku dan rumah ini juga menghadap ke arah barat (Lihat Gambar 9). Dan berikut adalah data - data yang didapat dari rumah dinas blok H 15.

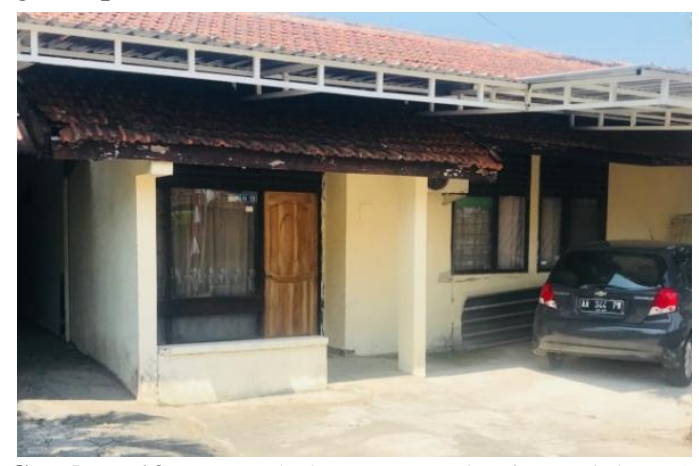

Gambar 12. Tampak depan Rumah Dinas Blok H 15.

\section{Metode kualitatif}

- Menggunakan dan menetap di rumah dinas Akpol terhitung mulai tanggal 01 Juli 1993.

- Untuk intensitas jendela dan suhu yang dirasakan beliau terasa cukup namun jendela kurang lebar bagi beliau, dan AC hanya terkadang digunakan serta ruangan teras terasa panas pada siang hingga sore hari. (Lihat Gambar 12)

- Untuk kelembaban dapat dilihat dari jamur yang terkadang tumbuh dalam hitungan normal dan menjadikan kondisi ruangan terasa cukup lembab. Tempiasan air hujan juga sering membasahi ruang tamu di kediamannya. (Lihat Gambar 12)

- Untuk air movement dari gerakan angin yang memasuki ruangan hanya terkadang saja dan dianggap normal namun membuat ruangan tidak terasa segar. (Lihat Gambar 12)

- Untuk nyamuk saat maghrib hanya sedikit yang datang.

- Sirkulasi udara diputuskan oleh beliau cukup memenuhi standar kaedah yang berlaku. (Lihat Gambar 12)

\section{Metode Kuantitatif}

Untuk rumah dinas blok $\mathrm{H} 15$ yang didapat dari metode kuantitatif adalah berdasarkan data - data tabel berikut : Metode kuantitatif rumah dinas Blok H 15 diukur dengan pengukuran kecepatan angin dalam " $\mathrm{m} / \mathrm{s}$ ” (Lihat tabel 21), kelembaban udara dalam " $R h$ " (Lihat tabel 22), dan temperatur efektif udara dalam ukuran " ${ }^{\circ} C$ ” (Lihat tabel 23).

Tabel 21. Kecepatan angin (m/s) di rumah dinas Blok H 15.

\begin{tabular}{|l|l|l|l|}
\hline $\begin{array}{l}\text { Rumah Dinas Blok H 15 } \\
\text { Kecepatan angin }(\mathrm{m} / \mathrm{s})\end{array}$ \\
\hline $\begin{array}{l}\text { Waktu } \\
\begin{array}{l}\text { Pengukura } \\
\mathrm{n}(\text { WIB })\end{array}\end{array}$ & $\begin{array}{l}\text { Kecepatan } \\
\text { Angin di Teras } \\
(\mathrm{m} / \mathrm{s})\end{array}$ & $\begin{array}{l}\text { Kecepatan } \\
\text { Angin di } \\
\text { Ruang } \\
\text { Keluarga } \\
(\mathrm{m} / \mathrm{s})\end{array}$ & $\begin{array}{l}\text { Kecepatan } \\
\text { Angin di } \\
\text { Ruang Tidur } \\
\text { Utama }(\mathrm{m} / \mathrm{s})\end{array}$ \\
\hline $05: 00$ & 0,17 & 0,17 & 0,16 \\
\hline
\end{tabular}




\begin{tabular}{|l|l|l|l|}
\hline $06: 00$ & 0,17 & 0,17 & 0,16 \\
\hline $08: 00$ & 0,18 & 0,17 & 0,17 \\
\hline $10: 00$ & 0,18 & 0,17 & 0,17 \\
\hline $12: 00$ & 0,17 & 0,17 & 0,17 \\
\hline $14: 00$ & 0,17 & 0,16 & 0,17 \\
\hline $16: 00$ & 0,18 & 0,17 & 0,17 \\
\hline $18: 00$ & 0,17 & 0,18 & 0,17 \\
\hline $20: 00$ & 0,17 & 0,17 & 0,16 \\
\hline $22: 00$ & 0,17 & 0,17 & 0,16 \\
\hline
\end{tabular}

Tabel 22. Kelembaban udara (Rh) di rumah dinas Blok H 15.

\begin{tabular}{|l|l|l|l|}
\hline $\begin{array}{l}\text { Rumah Dinas Blok H 15 } \\
\text { Kelembaban udara }(R h)\end{array}$ \\
\hline $\begin{array}{l}\text { Waktu } \\
\text { Pengukura } \\
\text { n (WIB) }\end{array}$ & $\begin{array}{l}\text { Kelembaban } \\
\text { udara di Teras } \\
(R h)\end{array}$ & $\begin{array}{l}\text { Kelembaban } \\
\text { udara di } \\
\text { Ruang } \\
\text { Keluarga }(R h)\end{array}$ & $\begin{array}{l}\text { Kelembaban } \\
\text { udara di Ruang } \\
\text { Tidur Utama } \\
(R h)\end{array}$ \\
\hline $05: 00$ & 78,6 & 78,6 & 79,6 \\
\hline $06: 00$ & 73,4 & 73,4 & 73,6 \\
\hline $08: 00$ & 66,5 & 66,5 & 66,5 \\
\hline $10: 00$ & 55 & 55,8 & 55,8 \\
\hline $12: 00$ & 45,7 & 46,7 & 46,7 \\
\hline $14: 00$ & 46,5 & 46,5 & 46,5 \\
\hline $16: 00$ & 55 & 55 & 55,8 \\
\hline $18: 00$ & 71,3 & 71,3 & 71,3 \\
\hline $20: 00$ & 73,5 & 76,5 & 76,5 \\
\hline $22: 00$ & 78,6 & 79,5 & 80,5 \\
\hline Rata- Rata & 64,4 & 65,0 & 65,3 \\
\hline
\end{tabular}

Tabel 23. Temperatur Udara $\left({ }^{0} \mathrm{C}\right)$ di rumah dinas Blok H 15.

\begin{tabular}{|l|l|l|l|}
\hline $\begin{array}{l}\text { Rumah Dinas Blok H 15 } \\
\text { Temperatur Udara }\left({ }^{\circ} C\right) .\end{array}$ \\
\hline $\begin{array}{l}\text { Waktu } \\
\text { Pengukura } \\
\text { n(WIB) }\end{array}$ & $\begin{array}{l}\text { Temperatur } \\
\text { Udara di } \\
\text { Teras }\left({ }^{\circ} C\right)\end{array}$ & $\begin{array}{l}\text { Temperatur } \\
\text { Udara di } \\
\text { Ruang } \\
\text { Keluarga } \\
\left({ }^{\circ} C\right)\end{array}$ & $\begin{array}{l}\text { Temperatur } \\
\text { Udara di Ruang } \\
\text { Tidur Utama } \\
\left({ }^{\circ} C\right)\end{array}$ \\
\hline $05: 00$ & 26,1 & 25,8 & 25,7 \\
\hline $06: 00$ & 25,3 & 25,7 & 25,3 \\
\hline $08: 00$ & 25,8 & 25,5 & 25,9 \\
\hline $10: 00$ & 26,3 & 25,9 & 26,1 \\
\hline $12: 00$ & 27,2 & 25,8 & 25,7 \\
\hline $14: 00$ & 25,9 & 25,9 & 25,7 \\
\hline $16: 00$ & 26,4 & 26,1 & 25,8 \\
\hline $18: 00$ & 25,8 & 25,7 & 26 \\
\hline 20:00 & 25,8 & 26,6 & 25,1 \\
\hline 22:00 & 26,2 & 24,8 & 25,4 \\
\hline Rata- Rata & 26,1 & 25,8 & 25,7 \\
\hline & & & \\
\hline
\end{tabular}

\subsection{Rumah Dinas Blok H 21}

Rumah dinas Blok H 21 adalah rumah dinas yang terletak pada jalan Duku dan menghadap ke arah barat (Lihat Gambar 9). Berikut ini adalah data - data yang didapat dari rumah dinas blok $\mathrm{H} 21$.

\section{Metode Kualitatif}

- Menggunakan dan menetap di rumah dinas Akpol sejak menjabat di Lemdiklat Polri - Akpol 24 November 2014.
- Rumah dinas di Akpol digunakan karena lebih fleksibel dan nyaman untuk ke lokasi area markas dan pelatihan karena beliau menjabat sebagai Wakadentar, Korbintarsis, Dit. Bintarlat.

- Untuk intensitas jendela sering digunakan dan sudah dirasakan sangat lebar oleh beliau dan AC hanya digunakan terkadang saja karena panas pada siang hingga sore sudah dapat dikatakan cukup. (Lihat Gambar 13)

- Untuk kelembaban jamur yang tumbuh hanya sedikit namun beliau merasakan tidak ada kelembaban di dalam rumah dan tidak ada tempiasan air hujan yang membasahi kediaman. (Lihat Gambar 13)

- Untuk air movement hanya terkadang saja gerakan angin yang masuk ke dalam rumah dan angin terasa nyaman serta membuat kondisi menjadi segar dan memudahkan untuk konsentrasi. (Lihat Gambar 13)

- Untuk kediaman ini tidak ada nyamuk yang berkunjung pada saat maghrib

- Dan dari semuanya menurut beliau sirkulasi udara sudah memenuhi standar kaedah yang berlaku.

\section{Metode Kuantitatif}

Untuk rumah dinas blok $\mathrm{H} 21$ yang didapat dari metode kuantitatif adalah berdasarkan data - data tabel berikut : Metode kuantitatif rumah dinas Blok H 21 diukur dengan pengukuran kecepatan angin dalam " $\mathrm{m} / \mathrm{s}$ " (Lihat tabel 24), kelembaban udara dalam " $R h$ " (Lihat tabel $25)$, dan temperatur efektif udara dalam ukuran " ${ }^{\prime 0} C$, (Lihat tabel 26).

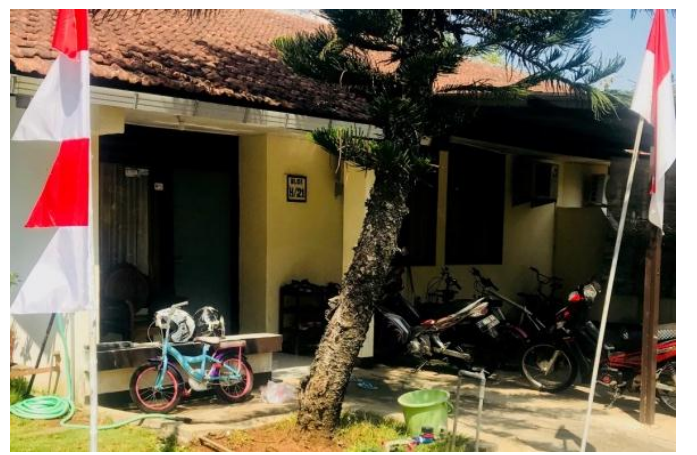

Gambar 13. Tampak depan Rumah Dinas Blok H 21.

Tabel 24. Kecepatan angin (m/s) di rumah dinas Blok H 21.

\begin{tabular}{|l|l|l|l|}
\hline \multicolumn{4}{|l|}{$\begin{array}{l}\text { Rumah Dinas Blok H 21 } \\
\text { Kecepatan angin }(\mathrm{m} / \mathrm{s})\end{array}$} \\
\hline $\begin{array}{l}\text { Waktu } \\
\text { Pengukura } \\
\mathrm{n}(\text { WIB })\end{array}$ & $\begin{array}{l}\text { Kecepatan } \\
\text { Angin di Teras } \\
(\mathrm{m} / \mathrm{s})\end{array}$ & $\begin{array}{l}\text { Kecepatan } \\
\text { Angin di } \\
\text { Ruang } \\
\text { Keluarga } \\
(\mathrm{m} / \mathrm{s})\end{array}$ & $\begin{array}{l}\text { Kecepatan } \\
\text { Angin di } \\
\text { Ruang Tidur } \\
\text { Utama }(\mathrm{m} / \mathrm{s})\end{array}$ \\
\hline $05: 00$ & 0,17 & 0,16 & 0,16 \\
\hline $06: 00$ & 0,17 & 0,16 & 0,16 \\
\hline $08: 00$ & 0,17 & 0,17 & 0,17 \\
\hline $10: 00$ & 0,17 & 0,17 & 0,17 \\
\hline $12: 00$ & 0,17 & 0,16 & 0,17 \\
\hline
\end{tabular}




\begin{tabular}{|l|l|l|l|}
\hline $14: 00$ & 0,17 & 0,16 & 0,17 \\
\hline $16: 00$ & 0,17 & 0,17 & 0,17 \\
\hline $18: 00$ & 0,18 & 0,17 & 0,17 \\
\hline $20: 00$ & 0,18 & 0,17 & 0,17 \\
\hline $22: 00$ & 0,17 & 0,17 & 0,16 \\
\hline
\end{tabular}

Tabel 25. Kelembaban udara (Rh) di rumah dinas Blok H 21

\begin{tabular}{|l|l|l|l|}
\hline \multicolumn{4}{|l|}{$\begin{array}{l}\text { Rumah Dinas Blok H 21 } \\
\text { Kelembaban udara }(R h)\end{array}$} \\
\hline $\begin{array}{l}\text { Waktu } \\
\begin{array}{l}\text { Pengukura } \\
\text { n (WIB) }\end{array}\end{array}$ & $\begin{array}{l}\text { Kelembaban } \\
\text { udara di Teras } \\
(R h)\end{array}$ & $\begin{array}{l}\text { Kelembaban } \\
\text { udara di } \\
\text { Ruang } \\
\text { Keluarga }(R h)\end{array}$ & $\begin{array}{l}\text { Kelembaban } \\
\text { udara di Ruang } \\
\text { Tidur Utama } \\
(R h)\end{array}$ \\
\hline $05: 00$ & 77,6 & 77,6 & 77,6 \\
\hline $06: 00$ & 72,9 & 72,9 & 72,9 \\
\hline $08: 00$ & 68 & 68 & 68 \\
\hline $10: 00$ & 55,2 & 55,2 & 55,2 \\
\hline $12: 00$ & 44,2 & 48,2 & 48,2 \\
\hline $14: 00$ & 50,6 & 50,6 & 50,6 \\
\hline $16: 00$ & 59,2 & 59,2 & 59,2 \\
\hline $18: 00$ & 71,5 & 71,6 & 70,6 \\
\hline 20:00 & 77 & 77 & 77 \\
\hline 22:00 & 77,6 & 78,4 & 78,4 \\
\hline Rata- Rata & 65,4 & 65,9 & 65,8 \\
\hline
\end{tabular}

Tabel 26. Temperatur Udara $\left({ }^{0} \mathrm{C}\right)$ di rumah dinas Blok H 21.

\begin{tabular}{|l|l|l|l|}
\hline $\begin{array}{l}\text { Rumah Dinas Blok H } 21 \\
\text { Temperatur Udara }\left({ }^{\circ} \mathrm{C}\right) .\end{array}$ \\
\hline $\begin{array}{l}\text { Waktu } \\
\text { Pengukura } \\
\text { n (WIB) }\end{array}$ & $\begin{array}{l}\text { Temperatur } \\
\text { Udara di } \\
\text { Teras }\left({ }^{\circ} \mathrm{C}\right)\end{array}$ & $\begin{array}{l}\text { Temperatur } \\
\text { Udara di } \\
\text { Ruang } \\
\text { Keluarga } \\
\left({ }^{\circ} \mathrm{C}\right)\end{array}$ & $\begin{array}{l}\text { Temperatur } \\
\text { Udara di Ruang } \\
\text { Tidur Utama } \\
\left({ }^{\circ} \mathrm{C}\right)\end{array}$ \\
\hline $05: 00$ & 23,4 & 25,5 & 24,3 \\
\hline $06: 00$ & 24,6 & 25 & 25,2 \\
\hline $08: 00$ & 25,8 & 25,4 & 26 \\
\hline $10: 00$ & 26,1 & 26,3 & 26 \\
\hline $12: 00$ & 26,4 & 26,4 & 26 \\
\hline $14: 00$ & 26,8 & 26,2 & 26,1 \\
\hline $16: 00$ & 25,9 & 26,3 & 26,2 \\
\hline $18: 00$ & 24,8 & 25,4 & 26 \\
\hline $20: 00$ & 25,1 & 25,8 & 25,3 \\
\hline $22: 00$ & 24 & 25,1 & 25,2 \\
\hline Rata- Rata & 25,3 & 25,7 & 25,6 \\
\hline & & & \\
\hline
\end{tabular}

\subsection{Rumah Dinas Blok H 23}

Rumah dinas Blok H 23 adalah rumah dinas yang terletak pada jalan Duku dan menghadap ke arah Timur serta berhadapan dan menjadi satu jalan dengan rumah dinas Blok H 15 dan H 21 (Lihat Gambar 9). Berikut ini adalah data - data yang didapat dari rumah dinas Blok $\mathrm{H}$ 23.

\section{Metode Kualitatif}

- Menggunakan dan menetap di rumah dinas Akpol untuk transit sejak Januari 2005.

- Rumah dinas di Akpol digunakan karena lebih fleksibel dan nyaman untuk ke lokasi area markas dan pelatihan karena beliau di kebanyakan instansi di Akpol walaupun ada rumah pribadi Kota Semarang.
- Untuk intensitas jendela sering digunakan dan sudah dirasakan cukup lebar oleh beliau dan AC tetap sering digunakan walaupun ruangan tidak terasa panas. (Lihat Gambar 14)

- Untuk kelembaban sudah dirasakan cukup dan ada juga jamur yang tumbuh normal serta dinding terasa basah saat even hujan berlangsung dan setelah reda, namun air hujan tidak membasahi area dalam ruangan. (Lihat Gambar 14)

- Untuk air movement dapat dirasakan adanya gerakan angin yang memasuki walaupun hanya terkadang dan terasa sangat nyaman dan membuat segar. (Lihat Gambar 14)

- Untuk nyamuk yang datang pada saat maghrib tidak terlalu banyak atau dikatakan sedikit jumlahnya.

- Dan menurut beliau semua sudah memenuhi standar dan kaedah yang berlaku untuk kelayakan tempat tinggalnya.

\section{Metode Kuantitatif}

Untuk rumah dinas blok $\mathrm{H} 23$ yang didapat dari metode kuantitatif adalah berdasarkan data - data tabel berikut : Metode kuantitatif rumah dinas Blok H 23 diukur dengan pengukuran kecepatan angin dalam " $\mathrm{m} / \mathrm{s}$ " (Lihat tabel 27), kelembaban udara dalam " $R h$ " (Lihat tabel 28), dan temperatur efektif udara dalam ukuran ${ }^{~}{ }^{0} C$ " (Lihat tabel 29)

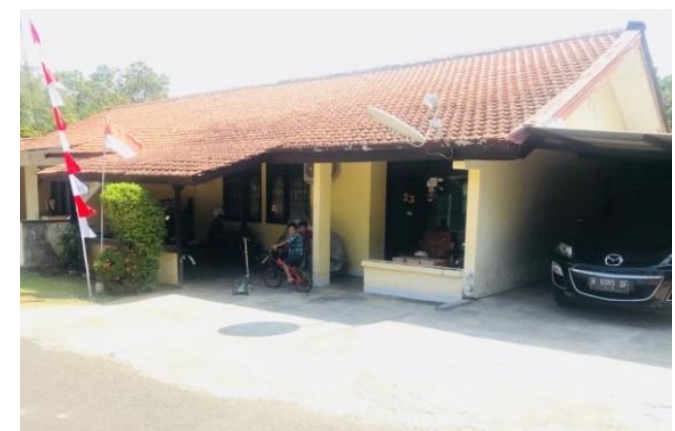

Gambar 14. Tampak depan Rumah Dinas Blok H 23.

Tabel 27. Kecepatan angin (m/s) di rumah dinas Blok H 23.

\begin{tabular}{|l|l|l|l|}
\hline $\begin{array}{l}\text { Rumah Dinas Blok H 23 } \\
\text { Kecepatan angin }(\mathrm{m} / \mathrm{s})\end{array}$ \\
\hline $\begin{array}{l}\text { Waktu } \\
\begin{array}{l}\text { Pengukura } \\
\text { n (WIB) }\end{array}\end{array}$ & $\begin{array}{l}\text { Kecepatan } \\
\text { Angin di Teras } \\
(\mathrm{m} / \mathrm{s})\end{array}$ & $\begin{array}{l}\text { Kecepatan } \\
\text { Angin di } \\
\text { Ruang } \\
\text { Keluarga } \\
(\mathrm{m} / \mathrm{s})\end{array}$ & $\begin{array}{l}\text { Kecepatan } \\
\text { Angin di } \\
\text { Ruang Tidur } \\
\text { Utama }(\mathrm{m} / \mathrm{s})\end{array}$ \\
\hline $05: 00$ & 0,17 & 0,16 & 0,16 \\
\hline $06: 00$ & 0,17 & 0,16 & 0,16 \\
\hline $08: 00$ & 0,17 & 0,17 & 0,17 \\
\hline $10: 00$ & 0,17 & 0,17 & 0,17 \\
\hline $12: 00$ & 0,17 & 0,16 & 0,17 \\
\hline $14: 00$ & 0,17 & 0,16 & 0,17 \\
\hline $16: 00$ & 0,17 & 0,17 & 0,17 \\
\hline $18: 00$ & 0,18 & 0,17 & 0,17 \\
\hline
\end{tabular}




\begin{tabular}{|l|l|l|l|}
\hline $20: 00$ & 0,18 & 0,17 & 0,17 \\
\hline $22: 00$ & 0,17 & 0,17 & 0,16 \\
\hline
\end{tabular}

Tabel 28. Kelembaban udara (Rh) di rumah dinas Blok H 23

\begin{tabular}{|l|l|l|l|}
\hline \multicolumn{4}{|l|}{$\begin{array}{l}\text { Rumah Dinas Blok H 23 } \\
\text { Kelembaban udara }(R h)\end{array}$} \\
\hline $\begin{array}{l}\text { Waktu } \\
\begin{array}{l}\text { Pengukura } \\
\text { n(WIB) }\end{array}\end{array}$ & $\begin{array}{l}\text { Kelembaban } \\
\text { udara di Teras } \\
(R h)\end{array}$ & $\begin{array}{l}\text { Kelembaban } \\
\text { udara di } \\
\text { Ruang } \\
\text { Keluarga }(R h)\end{array}$ & $\begin{array}{l}\text { Kelembaban } \\
\text { udara di Ruang } \\
\text { Tidur Utama } \\
(R h)\end{array}$ \\
\hline $05: 00$ & 78 & 78 & 78 \\
\hline $06: 00$ & 72,5 & 72,5 & 72,5 \\
\hline $08: 00$ & 66,8 & 66,8 & 66,8 \\
\hline $10: 00$ & 55 & 55 & 55 \\
\hline $12: 00$ & 43,7 & 47,7 & 47,7 \\
\hline $14: 00$ & 49,7 & 49,7 & 49,7 \\
\hline $16: 00$ & 55 & 55 & 55,2 \\
\hline $18: 00$ & 71,4 & 71,4 & 71,4 \\
\hline $20: 00$ & 73,5 & 75,5 & 75,5 \\
\hline $22: 00$ & 79,5 & 80,5 & 80,5 \\
\hline Rata- Rata & 64,5 & 65,2 & 65,2 \\
\hline
\end{tabular}

Tabel 29. Temperatur Udara $\left({ }^{0} \mathrm{C}\right)$ di rumah dinas Blok H 23.

\begin{tabular}{|l|l|l|l|}
\hline $\begin{array}{l}\text { Rumah Dinas Blok } \mathrm{H} 23 \\
\text { Temperatur Udara }\left({ }^{\circ} \mathrm{C}\right) .\end{array}$ \\
\hline $\begin{array}{l}\text { Waktu } \\
\text { Pengukura } \\
\mathrm{n} \text { (WIB) }\end{array}$ & $\begin{array}{l}\text { Temperatur } \\
\text { Udara di } \\
\text { Teras }\left({ }^{\circ} \mathrm{C}\right)\end{array}$ & $\begin{array}{l}\text { Temperatur } \\
\text { Udara di } \\
\text { Ruang } \\
\text { Keluarga } \\
\left({ }^{\circ} \mathrm{C}\right)\end{array}$ & $\begin{array}{l}\text { Temperatur } \\
\text { Udara di Ruang } \\
\text { Tidur Utama } \\
\left({ }^{\circ} \mathrm{C}\right)\end{array}$ \\
\hline $05: 00$ & 26,1 & 25,7 & 25,6 \\
\hline $06: 00$ & 25,1 & 25,3 & 25,2 \\
\hline $08: 00$ & 25,8 & 25,5 & 25,9 \\
\hline $10: 00$ & 26,3 & 25,8 & 26,2 \\
\hline $12: 00$ & 26,2 & 26,3 & 26,2 \\
\hline $14: 00$ & 26 & 26,1 & 26 \\
\hline $16: 00$ & 25,9 & 26,2 & 25,8 \\
\hline 18:00 & 25,8 & 26,4 & 26,1 \\
\hline $20: 00$ & 25,9 & 26,1 & 25,2 \\
\hline $22: 00$ & 26,4 & 25,8 & 25,8 \\
\hline Rata- Rata & 26,0 & 25,9 & 25,8 \\
\hline
\end{tabular}

\subsection{Rumah Dinas Blok H 28}

Rumah dinas Blok H 28 adalah rumah dinas yang terletak pada jalan Duku dan juga menghadap ke arah Timur serta berjajar dengan rumah dinas Blok $\mathrm{H} 23$ dan berhadapan dengan rumah dinas Blok H 21 (Lihat Gambar 9).

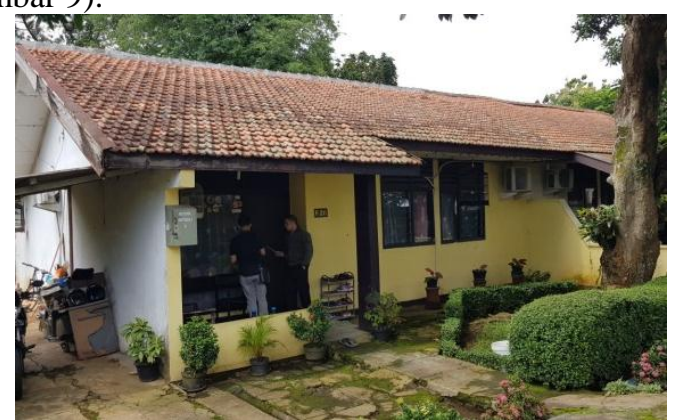

Gambar 15. Tampak depan Rumah Dinas Blok H 28.

\section{Metode Kualitatif}

- Menggunakan dan menetap di rumah dinas Akpol sejak 06 Desember 1998.

- Rumah dinas di Akpol fleksibel untuk digunakan beliau karena beliau fokus pada program pendidikan dan dapat disalurkan ke jajaran para siswa yang berada di Lemdiklat Polri - Akpol.

- Untuk intensitas jendela sering digunakan dan sudah dirasakan cukup lebar oleh beliau dan AC tetap sering karena ruangan cukup terasa panas bagi beliau. (Lihat Gambar 15)

- Untuk kelembaban dirasakan sangat tinggi dan ada juga jamur yang tumbuh serta dinding terasa basah saat even hujan berlangsung dan setelah reda, namun air hujan tidak membasahi area dalam ruangan. (Lihat Gambar 15)

- Untuk air movement dapat dirasakan adanya gerakan angin yang memasuki walaupun hanya terkadang dan terasa sangat nyaman dan membuat segar dan tidak sulit untuk berkonsentrasi. (Lihat Gambar 15)

- Untuk nyamuk yang datang pada saat maghrib tidak terlalu banyak atau dikatakan sedikit jumlahnya.

- Dan menurut beliau semua sudah memenuhi standar dan kaedah yang berlaku untuk kelayakan tempat tinggalnya.

\section{Metode Kuantitatif}

Untuk rumah dinas blok $\mathrm{H} 28$ yang didapat dari metode kuantitatif adalah berdasarkan data - data tabel berikut : Metode kuantitatif rumah dinas Blok H 28 diukur dengan pengukuran kecepatan angin dalam " $\mathrm{m} / \mathrm{s}$ ” (Lihat tabel 30), kelembaban udara dalam "Rh" (Lihat tabel 31), dan temperatur efektif udara dalam ukuran ${ }^{~ " ~} C$ " (Lihat tabel 32).

Tabel 30. Kecepatan angin $(\mathrm{m} / \mathrm{s})$ di rumah dinas Blok H 28.

\begin{tabular}{|l|l|l|l|}
\hline $\begin{array}{l}\text { Rumah Dinas Blok H } 28 \\
\text { Kecepatan angin }(\mathrm{m} / \mathrm{s})\end{array}$ \\
\hline $\begin{array}{l}\text { Waktu } \\
\begin{array}{l}\text { Pengukura } \\
\mathrm{n}(\text { WIB })\end{array}\end{array}$ & $\begin{array}{l}\text { Kecepatan } \\
\text { Angin di Teras } \\
(\mathrm{m} / \mathrm{s})\end{array}$ & $\begin{array}{l}\text { Kecepatan } \\
\text { Angin di } \\
\text { Ruang } \\
\text { Keluarga } \\
(\mathrm{m} / \mathrm{s})\end{array}$ & $\begin{array}{l}\text { Kecepatan } \\
\text { Angin di } \\
\text { Ruang Tidur } \\
\text { Utama }(\mathrm{m} / \mathrm{s})\end{array}$ \\
\hline $05: 00$ & 0,18 & 0,18 & 0,18 \\
\hline $06: 00$ & 0,19 & 0,18 & 0,18 \\
\hline $08: 00$ & 0,18 & 0,17 & 0,17 \\
\hline $10: 00$ & 0,18 & 0,17 & 0,17 \\
\hline $12: 00$ & 0,17 & 0,17 & 0,17 \\
\hline $14: 00$ & 0,17 & 0,17 & 0,17 \\
\hline $16: 00$ & 0,17 & 0,17 & 0,17 \\
\hline $18: 00$ & 0,17 & 0,17 & 0,18 \\
\hline $20: 00$ & 0,17 & 0,17 & 0,17 \\
\hline $22: 00$ & 0,18 & 0,17 & 0,17 \\
\hline
\end{tabular}


Tabel 31. Kelembaban udara (Rh) di rumah dinas Blok H 28

\begin{tabular}{|l|l|l|l|}
\hline \multicolumn{4}{|l|}{$\begin{array}{l}\text { Rumah Dinas Blok H 28 } \\
\text { Kelembaban udara }(R h)\end{array}$} \\
\hline $\begin{array}{l}\text { Waktu } \\
\begin{array}{l}\text { Pengukura } \\
\text { n (WIB) }\end{array}\end{array}$ & $\begin{array}{l}\text { Kelembaban } \\
\text { udara di Teras } \\
(R h)\end{array}$ & $\begin{array}{l}\text { Kelembaban } \\
\text { udara di } \\
\text { Ruang } \\
\text { Keluarga }(R h)\end{array}$ & $\begin{array}{l}\text { Kelembaban } \\
\text { udara di Ruang } \\
\text { Tidur Utama } \\
(R h)\end{array}$ \\
\hline $05: 00$ & 78,6 & 78,6 & 78,6 \\
\hline $06: 00$ & 72,8 & 72,8 & 72,8 \\
\hline $08: 00$ & 69 & 69 & 69 \\
\hline $10: 00$ & 55,3 & 54,3 & 54,3 \\
\hline $12: 00$ & 45,5 & 45,5 & 47,5 \\
\hline $14: 00$ & 50,5 & 50,5 & 50,5 \\
\hline $16: 00$ & 55 & 55 & 55 \\
\hline $18: 00$ & 71 & 71 & 71 \\
\hline 20:00 & 73,5 & 76,5 & 76,5 \\
\hline 22:00 & 78,6 & 81,5 & 81,5 \\
\hline Rata- Rata & 65,0 & 65,5 & 65,7 \\
\hline
\end{tabular}

Tabel 32. Temperatur Udara $\left({ }^{0} \mathrm{C}\right)$ di rumah dinas Blok H 28.

\begin{tabular}{|l|l|l|l|}
\hline $\begin{array}{l}\text { Rumah Dinas Blok } \mathrm{H} 28 \\
\text { Temperatur Udara }\left({ }^{\circ} \mathrm{C}\right) .\end{array}$ \\
\hline $\begin{array}{l}\text { Waktu } \\
\begin{array}{l}\text { Pengukura } \\
\text { n (WIB) }\end{array}\end{array}$ & $\begin{array}{l}\text { Temperatur } \\
\text { Udara di } \\
\text { Teras }\left({ }^{\circ} \mathrm{C}\right)\end{array}$ & $\begin{array}{l}\text { Temperatur } \\
\text { Udara di } \\
\text { Ruang } \\
\text { Keluarga } \\
\left.{ }^{0} \mathrm{C}\right)\end{array}$ & $\begin{array}{l}\text { Temperatur } \\
\text { Udara di Ruang } \\
\text { Tidur Utama } \\
\left({ }^{\circ} \mathrm{C}\right)\end{array}$ \\
\hline $05: 00$ & 26,1 & 25,7 & 25,6 \\
\hline $06: 00$ & 25,1 & 25,3 & 25,2 \\
\hline $08: 00$ & 26 & 25,7 & 26,1 \\
\hline $10: 00$ & 26,4 & 25,7 & 26,1 \\
\hline $12: 00$ & 26,2 & 25,5 & 25,8 \\
\hline $14: 00$ & 26,8 & 26,2 & 26,1 \\
\hline $16: 00$ & 26,8 & 25,8 & 26 \\
\hline $18: 00$ & 25,8 & 25,6 & 25,9 \\
\hline $20: 00$ & 25,7 & 25,8 & 25,3 \\
\hline $22: 00$ & 26,3 & 26,2 & 25,6 \\
\hline Rata- Rata & 26,1 & 25,8 & 25,8 \\
\hline
\end{tabular}

\section{KESIMPULAN}

Berdasarkan penelitian beserta data - data kualitatif dan kuantitatif yang didapat maka dapat ditarik sebuah kesimpulan dari hasil wawancara beserta pengamatan perhitungan dari segi kecepatan angin dalam $(\mathrm{m} / \mathrm{s})$, kelembaban udara dalam $(\mathrm{Rh})$, dan temperatur efektif dalam $\left({ }^{0} \mathrm{C}\right)$ maka mayoritas para penghuni lebih memilih menetap di asrama polisi karena dekat dengan tempat mereka berdinas serta dikarenakan faktor lingkungannya yang aman, nyaman, tenang dan asri karena sudah sesuai bagi para personil untuk melepaskan penat. Selain itu juga keakraban antar tetangga memunculkan rasa nyaman yang lebih serta aman bagi penghuni. Faktor lain juga dari udara lingkungan yang bersih dan bebas dari polusi membuat penghuni lebih memilih untuk menetap daripada membeli atau menyewa hunian yang baru.

\section{UCAPAN TERIMA KASIH}

Terimakasih kepada Universitas Diponegoro, kepada Lembaga Pendidikan dan Pelatihan Kepolisian Republik Indonesia "Lemdiklat Polri" khususnya beserta kepada Lembaga Pendidikan Dan Pelatihan Kepolisian Republik Indonesia - Akademi Kepolisian "Lemdiklat Polri - Akpol" , karena telah memberikan izin dan kesempatan untuk melakukan penelitian ini dan juga untuk dukungannya dalam menyediakan data - data yang digunakan terkait penelitian.

\section{DAFTAR PUSTAKA}

\section{Buku}

Cinthya ABP et al (2016) Perbandingan Waktu Biaya dan Sumber Daya Manusia Antara Metode Building Information Modelling (BIM) dan Konvensional (studi kasus Perancangan Gedung 20 Lantai), Jurnal Karya Teknik Sipil, vol 5 no 2 p 220-229

Arikunto, Suharsimi. 2002. Prosedur Penelitian : Suatu Pendekatan Praktek. Rineka Cipta. Jakarta.

Bell, Paul A.(1978).Environmental Psychology. Fifth Edition.United Kingdom.

Doxiadis, C. A. (1971). 'Ekistics, the science of human settlements'. Science. doi: 10.1126/science.170.3956.393.

Ekman, P., \& Friesen, W.V. (1978). Manual for the facial action coding system. Consulting Psychologists Press.

Fudyartana, Ki. (2012). Psikologi Kepribadian :Paradigma Filosofis, Tipologis, Psikodinamik, dan Organismik-Holistik. Pustaka Pelajar. Yogyakarta.

Husein Umar, Prof.Dr. (2019). Metode Riset Manajemen Perusahaan, Langkah Cepat dan Tepat Menyusun Tesis dan Desertasi. PT. Gramedia Pustaka Utama. Jakarta.

Idealistina, F. (1991). Model Termoregulasi Tubuh untuk Penentuan Besaran Kesan Thermal Terbaik dalam kaitannya dengan Kinerja Manusia, thesis doktor, Institut Teknologi Bandung, Bandung. Indonesia.

Kuswartojo, T. and Salim, S. A. (1997). Perumahan dan Permukiman yang Berwawasan Lingkungan. Direktorat Jenderal Pendidikan Tinggi, Departemen Pendidikan dan Kebudayaan. Jakarta.

Lippsmeier, Georg. (1994). Bangunan Tropis Erlangga. Jakarta.

Sarmanu. (2004). Metodologi Penelitian, Kumpulan Materi Pelatihan Structural Equation Modeling. Lembaga Penelitian Universitas Airlangga. Surabaya.

Setyowati, Erni. (2015). Fisika Bangunan 2 Thermal dan Accoustic. CV Tiga Media Pratama. Semarang. 
Sugiyono, Prof. Dr. (2013). Metode Penelitian Kuantitatif, Kualitatif, dan R\&D. .Alfabeta. Bandung.

\section{Jurnal - Jurnal}

Hoppe, P. 1988. Comfort Requirement in indoor climate, energy and buildings. ASHRAE Vol 11 Hal 249=267.

Houghton dan Yaglou. 1923. Determining Lines of Equal Comfort : Transactions of America Society of Heating and Ventilating Engineers Vol 29.

Karyono, Tri Harso. 2001. Wujud Kota Tropis di Indonesia : Suatu Pendekatan Iklim, Lingkungan, dan Energi. Jurnal Dimensi Teknik Arsitektur Vol. 29 No.2 Desember 2001 Halaman 141-146.

Napitupulu, Sally Septania. 2014. Pengaruh Orientasi Bangunan dan Kecepatan Angin Terhadap Bentuk dan Dimensi Filter Pada Fasad Bangunan Rumah Susun. Jurnal Arsitektur Vol 1 No 2.

Rilatupa, J. 2008. Aspek Kenyamanan Termal Pada Pengkondisian Ruang Dalam. Jurnal Sains dan Teknologi EMAS Vol 18 No.3

Susilowati, Diana dan Feri Wahyudi. 2014. Kajian Pengaruh Penerapan Arsitektur Tropis Terhadap Kenyamanan Thermal Pada Bangunan Publik Menggunakan Software Ecotech, Studi Kasus : Perpustakaan Universitas Indonesia. Jurnal Desain Komunikasi Vol 13 No.2 Desember 2014. Hal 22-34 